\title{
Spatial Variation of Sub-national Fertility Trends in Austria, Germany and Switzerland
}

\author{
Stuart Basten, Johannes Huinink, Sebastian Klüsener
}

\begin{abstract}
Sub-national trends in fertility are of great importance for policy makers and regional planners. This paper aims to provide a theoretical and empirical framework for policy makers, taking into account past and present trends in fertility, as well as their theoretical underpinnings. These will, we argue, be crucial in determining future trajectories and potential political responses to them.

The theoretical part of the paper deals with the factors that may influence fertility differences at the sub-national level, including decisions and life course trajectories at the individual level, as well as contextual socio-economic phenomena operating at different geographical levels (local, regional, national, global). This is followed by an empirical section, which takes the Eurostat publications on spatial fertility differences in Europe as a starting point. In an attempt to overcome the limitations of these reports - both in terms of the lack of geographic detail and the short time span covered - we provide more thorough overviews for Austria, Germany and Switzerland. Using historical data from the Princeton European Fertility Project and other sources, we have been able to reconstruct comparative regional fertility time series for the past 150 years. Finally, we present a case study on local fertility development in the municipalities and unified rural communities of the German state of Lower Saxony and the districts of the German city of Bremen.

Based on the results of this analysis, we conclude that the recent degree of fertility convergence between regions within countries - particularly at the macroregional level - is, indeed, striking. However, taking a long-term perspective, we are able to identify some substantial time periods over the last 150 years in which regional fertility levels diverged. This implies that the current picture must not necessarily constitute Fukuyama's "end of history" over the coming decades. Moreover, the study of local-level data reveals that, in contrast to the overall macro-regional fertility convergence process in all three countries, a trend towards divergence can be observed within the city of Bremen. This demonstrates that local divergence can run parallel to overall regional convergence.
\end{abstract}

Keywords: Fertility $\cdot$ NUTS-2 $\cdot$ Spatial variation $\cdot$ Sub-national fertility 


\section{Introduction}

The articles of Sobotka et al. (CPoS 36,2-3) and Philipov/Bernardi (CPoS 36,2-3) have considered the individual and social decision-making processes which affect childbearing in German-speaking countries. In this article, we place a greater emphasis upon the spatial dynamics. Over the last few centuries, we have witnessed increased integration of localities into nation-states, global networks and institutions. As a result, today's local conditions are heavily influenced by structures and processes operating at the national, supranational and global levels (Giddens 1990). Naturally, this has implications for spatial differentials in demographic behaviour. For example, in From Provinces into Nations, Susan Watkins observed that, in "1870 national boundaries were faint on the demographic map of western Europe; by 1960, they were deeply etched" (Watkins 1991: xiii). Despite this, she predicted that national boundaries of states will become less relevant as demographic divides due to European integration and globalisation processes (see also Agnew 2008).

In order to better anticipate future trends, it is crucial to know both the theoretical underpinnings of these spatial differentials, and the empirical studies on current developments. Thus, in Section 2, we present a review combining the theoretical background and a review of the literature. This highlights the key factors which are likely to drive future trajectories of sub-national fertility. Having established the theoretical framework for examining sub-national trends of fertility, we demonstrate some of these features empirically. This is based on Eurostat's Regional Yearbooks (e.g. Eurostat 2010a), which include data on sub-national fertility, and on how they relate to other population trends, with a particular focus on the NUTS-2 level. ${ }^{1}$

We extend the empirical analysis performed in the Eurostat reports in a number of ways. First, we integrate data from other sources to examine longer-term patterns in regional fertility. This allows us to place the current evidence in a much broader temporal context. Fundamental to our understanding of patterns of subnational fertility are the geographic units that we elect to employ. In order to provide a comprehensive cross-continental comparative framework, the Eurostat reports are uniform in their examination of regional fertility at the NUTS-2 level. However, even among these three German-speaking countries, the NUTS levels at which a regional "affiliation" is felt, or at which regional policy is shaped, are each different: the Swiss cantons (NUTS-3), the Austrian Bundes/änder (NUTS-2) and the German Bundesländer (NUTS-1). In Germany, in addition to the Bundesländer level, the NUTS-2 level is also of relevance for regional identification. This level consists of smaller Bundesländer and the Regierungsbezirke of bigger Bundesländer. We therefore present evidence from the most appropriate country-specific NUTS level.

1 All statistics at the regional level within the EU are based on the nomenclature of territorial units for statistics (NUTS). The NUTS classification has been used for regional statistics for many decades, and has always formed the basis for regional funding policy. It was only in 2003 , though, that NUTS acquired a legal basis, when the NUTS regulation was adopted by the Parliament and the Council. (For a full explanation, see Eurostat 2010b). 
Second, we perform an empirical analysis using small-scale local data to detect more nuanced patterns at a specific level. A crucial caveat is that NUTS regions are frequently highly artificial, and cut across established cultural boundaries. For the small-scale analysis, we compiled data on the municipalities and unified rural communities (Samtgemeinden) of the north German state of Lower Saxony (Niedersachsen), and information on the districts (Stadtteile) of the German city of Bremen. The latter belongs to the city-state of Bremen, and constitutes an enclave within the state of Lower Saxony. Our analysis covers the period 1971-2006. To our knowledge, there is no other existing dataset that provides fertility trends in a predominantly German-speaking area on such a small geographic scale, and over such a long period of time. Furthermore, such micro-analyses of fertility are relatively rare given the tendency of social scientists to unreflectively gravitate towards the use of easily accessible national level data and nations as units of comparative analysis, otherwise known as the "whole-nation bias" (Snyder 2001).

Socio-geographical analyses of fertility are relatively rare in the current policy literature (Boyle 2003). This may be because it is widely assumed that, in modern and post-modern societies, fertility patterns gradually converge within and across countries, and because there is evidence that convergence at certain NUTS levels is indeed taking place. But, like other expectations about the consequences of modernisation, this convergence may not materialise. By combining the latest empirical and theoretical evidence for these three countries, we hope to build on the articles of Sobotka et al. (in CPoS 36,2-3) and Philipov/Bernardi (in CPoS 36,2-3), and thereby provide some firmer foundations upon which our assumptions about the future of fertility in German-speaking countries can be based.

\section{Theoretical approaches to the social geography of fertility}

\subsection{What causes regional fertility differences in contemporary Europe?}

Regional effects on fertility behaviour are not easy to identify. In general, one can assume that they stem from different aspects of the living conditions of individuals - which we refer to as the "local opportunity structure" - in the regional or the local context which influence the incentive structure of potential parents and their children in different ways. However, this is not the whole story.

A more adequate approach (e.g. Werlen 1995) differentiates between two groups of mechanisms - compositional and contextual effects - that can contribute to regional fertility differences. Compositional effects are caused by the fact that inhabitants of different regions (e.g. different administrative units) are distributed differently with regard to individual-level characteristics related to fertility behaviour, such as educational attainment or socio-economic status. Contextual effects are caused by the fact that aspects of the local opportunity structure in regions in which the individuals live encourage or discourage them to have children. The composition of a region's population with regard to a certain attribute can, at the same time, also be a relevant contextual factor. If, for example, a region is mostly inhab- 
ited by individuals with a conservative world view, this might provide a conservative societal context. The latter may also affect the decisions of individuals with a nonconservative world view, who may choose to engage in conservative behaviour to avoid diminishing their local social capital.

The local opportunity structure encompasses:

(1) the material and institutional (infra-)structure, including the degree of urbanisation, the level of family-relevant services, other local conditions of family life and housing, and other place-related issues, such as environmental factors;

(2) economic conditions and prospects on the local labour market, which may, for example, be indicated by the level of unemployment, the availability of attractive jobs and the degree to which the local economy supports the workfamily balance;

(3) socio-structural factors in the area of residence, such as the degree of socio-economic segregation or the socio-structural composition of the partner market;

(4) cultural factors which contribute to a localised social climate, such as fertilityand family-related values, gender roles and social norms; and

(5) embeddedness in local social contexts, such as neighbourhoods, local kin and networks of friends.

The local opportunity structure of regions and particularly their socio-structural composition is strongly interlinked with interregional migration which, therefore, is of fundamental importance in the analysis of regional specific fertility. Selective migration can contribute to the selectivity of both stayers and movers with regard to relevant individual attributes. In a typology, Huinink and Wagner (1989: 673) disentangled the interplay between regional effects and migration outcomes on individual behaviour, which allows for a better explanation of regional-level fertility parameters. With regard to movers from a region $A$ to a region $B$, we can distinguish (at least) three sub-cases, which are also considered in the current literature (Kulu/ Milewski 2007):

Assimilators: Movers change their behaviour in response to the different fertility-related local opportunity structure in regions $A$ or $B$. They adapt to the new regional environment in region $B$. In their region of origin $A$, they behaved in line with the behavioural pattern predominant in region $A$. This assimilative behavioural pattern contributes positively to the difference in regional level fertility parameters. This is referred to in the literature as the adaptation hypothesis.

Context selectors: Movers move to region B, because it is more suitable for their intended fertility behaviour. They should be distinct among the population of the region of origin $A$ due to the fact that they anticipate such a move. Because this case requires that the relevant local opportunity structure in the region of destination $B$ is different from that of region $A$, we observe an indirect regional effect on the migration decision which amplifies the regional difference in the level of fertility parameters. In the literature, this is called the selection hypothesis. 
Persistently socialised: Movers stick to the behaviour they learned in the region of origin A and probably differ from the stayers in region B. This tends to decrease the contrast in fertility parameters between regions. In the literature, this is called the socialisation hypothesis.

A number of studies have supported one or the other of these hypotheses (Ku/u 2005; Kulu/Boyle 2009), but more research is needed. Long-term longitudinal data would allow examining the effects of residential relocation on the fertility of migrants more closely. In any case, our understanding of the fertility patterns of migrants is that they are shaped by the spatial and compositional contextual factors in both the sending and the receiving areas which will be outlined below.

\subsection{Material and institutional infra-structure}

The degree of urbanisation is an important factor in regional patterns of fertility. To explain the low fertility in cities, we can refer to the familiar argument that living in an urban area should decrease the motivation to have children, because these areas offer more attractive alternatives to family life (Hank 2002) - i.e. the opportunity costs of having children are higher in cities. A second set of arguments revolve around different living conditions for families: the architectural environment is said to provide less room for young children's activities and for larger families, and to be too unsafe to allow children to play and spend time outdoors without parental supervision. The social environment is characterised by anonymity and a dearth of relationships with trusted individuals outside the family. Thus, cities are often seen as less safe settings for children to grow up in, which could encourage selective migration of families to the suburbs.

However, the quantity and quality of the provision of facilities essential for daily living may, in fact, be better in cities than in rural areas. The same is true for the density of day care facilities. This is positive for families. The favourable infrastructure, which provides families with a means of organising daily life, might make living in cities more attractive. Cities could be a better place for parents to combine family-related tasks with their interests in other life domains (e.g. career opportunities), and to balance the pursuit of career and personal interests with child-rearing and parenting. These considerations are becoming increasingly important as more young couples pursue a wider variety of non-family activities. Given the trend towards urbanisation in Europe and throughout the world, this effect could probably play a greater role.

Different regions have different levels of family-related services, like day care facilities, both formal and informal. The extent to which these services are available should be relevant for individual fertility behaviour, because they make it easier to balance family and work. In particular the interaction of child care provision with other local/regional family policy measures (Neyer/Andersson 2008; Baizán 2009) could play a significant role in extent to which these measures shape fertility.

Another aspect causing strong compositional effects on regional period fertility measures is the existence or absence of post-secondary and tertiary institutions of education. Most of these institutions are located in urban centres. These regions 
usually experience a substantial in-migration of young men and women who are attending those institutions. Most of them do not intend to have children while they are students, and postpone starting a family until after they have finished their studies (e.g. Blossfeld/Huinink 1991; Kreyenfeld/Mika 2008). And before starting a family, a substantial number of women will have left the area where they studied. As a result, university towns are reporting very low period total fertility rates (TFR) today, sometimes even below 1.0 (e.g. the German town Heidelberg with a TFR of 0.95 in 2006; Statistisches Landesamt Baden-Würtemberg 2007).

\subsection{Local economic conditions}

The local economic conditions and prospects in the regional labour market must be considered as well. Again, the assumed correlation with fertility behaviour is not clear-cut. It also depends to some extent on the welfare state policies and local family support systems (e.g. unemployment support, provision of day care facilities). A positive relationship between economic prosperity and good labour market prospects for women on the one hand, and fertility on the other, may be expected if the opportunity costs of childrearing can be kept sufficiently low. Then one can observe a pro-cyclical development of birth rates as found in Sweden (Andersson 2000). If the opportunity costs are high, they may even increase together with labour market prospects. In this case, fertility tends to be low, and patterns of polarisation in regard to the number of children can be observed (Huinink 2002).

Another factor is housing, which encompasses both housing conditions and the regional housing market (Mulder 2006a/b). We can, however, assume, that housing is more likely to affect selective migration than to influence fertility plans directly (Mulder/Wagner 2001; Kulu/Vikat 2008). However, the emergence in recent years of footloose industries and services, as well as teleworking, has, at least for some groups of actors, provided opportunities to move to rural areas with easier access to housing, without substantially affecting income opportunities. Finally, we may want to consider region-related features or aspects of the natural environment ( $\mathrm{An}$ derson 1986). In contemporary European countries, however, these features might be of minor importance.

\subsection{Socio-structural factors}

The local conditions and the socio-economic composition of the local partner and marriage market, which enables single people to establish sufficiently satisfying relationships, is an important regional factor in family development (Lichter et al. 1991; Lloyd/South 1996). The probability of spatial homogamy is considerable (Haandrikman et al. 2008; Haandrikman et al. 2010).

The socio-economic composition, or the segregation of the population of a region or a local area, is important in many other aspects. While it operates less through direct effects on fertility beyond the related individual characteristics, the socio-economic composition is correlated with the infrastructure of an area, and the area's (sub-) culture and social climate. It is also shown that there are strong correla- 
tions between indicators of the composition of the population by socio-economic status or ethnicity, and the level of fertility in regions. A good example is urban districts as regional units (Strohmeier/Kersting 1996; Hank 2002).

\subsection{Cultural factors}

The theory of the "second demographic transition" (SDT) posits that secularisation and religiosity, the level of individualisation and the relevance of postmodern values and life goals, i.e. ideational change, are important causes of changing fertility behaviour (Lesthaeghe/Nee/s 2002; Lesthaeghe/Neidert 2006). Indeed, it is argued that apart from the effects of selective migration, the social control of fertility is among the decisive features that explain (stable) regional differences in both levels of fertility and the onset of change (Lesthaeghe 1980). The relevance of cultural patternsafter socio-economic differences are taken into account-has been shown for a number of countries (Knodel 1974; Anderson 1986; Nauck 1995). For example, the Princeton Project found that differences in fertility levels between culturally heterogeneous regions are greater than rural-urban disparities (Sharlin 1986). However, this can also be an artefact of using provinces as the unit of analysis. Based on more fine-grained data for the Prussian districts, and contrasting Protestant and Catholic areas by urbanisation degree, the findings of Sharlin can only be confirmed for the pre-first demographic transition period (Klüsener/Goldstein 2012).

According to Inglehart value change is driven by the succession of cohorts growing up in the (local) socio-cultural and economic setting of their parents (Ing/ehart 1977). He assumes the cohort members themselves do not change their individual values over the rest of their life. Even though this kind of "socialisation hypothesis" is debatable theoretical and empirical evidence support it at least in part. We can assume that stable socialisation effects are in action at least for stayers in a certain region, where a stronger social control by kin might increase the likelihood of adhering to intergenerational norms. In this case, value change is not just slow, but cultural patterns are also linked to the region through socialisation and transmission mechanisms. It had been anticipated that, with advancing modernity and the increasing universalism of values, this regional link would be weakened. However, it seems that regional attachments remain strong. Why should proven practices for organising life change so quickly or drastically that the regional community reject these norms overnight? Thus, it has often been observed that people in rural areas are more prone to hold traditional values, to be religious and to adhere to conventional family norms.

When studying how cultural factors work, Szreter's "communication community" is a helpful concept. It arose from the observation that there are huge differences in fertility among people with the same status in different regions of England in the early 20th century (Szreter 1996). In his study of fertility in Britain in 1860 to 1940, Szreter assumed that fertility behaviour is the outcome of a complex interaction between individual characteristics, structural conditions in the region and customised patterns of courtship, marriage and childrearing behaviour. Communication communities are not necessarily restricted to a certain region. They unite 
groups of people "striving after similar social and cultural goals and adopting similar gender and work roles and sharing a similar language" (Szreter 1996: 546). They encompass complex codes that are learned and internalised during early life, in the family and in the neighbourhood. Even though this concept was developed as part of an historical study, the principle behind it could still be useful in understanding the relevance of local social norms established and stabilised by social exchange and interaction (Blau 1977).

Another concept which addresses the relevance of culture is social climate (Adriaanse 2007). It connects cultural issues with the interaction structure in communities. Szreter's concept of a communication community had emphasised the relevance of family and neighbourhood in the transmission process of cultural values and norms. He also noted the existence of reinforcing processes, which stabilise such contexts (Szreter 1996). These processes take place in a complex grid of social relationships, in which social approval and esteem play important roles for the behaviour of individuals. The social context that makes up the social climate usually has a local basis, even though old-fashioned neighbourhoods no longer exist, and regional ties are less apparent (but are not completely lost).

\subsection{Embeddedness in social relationships and networks}

Social interaction in social networks is a particular dimension of the local environment which affects fertility and, importantly, migration decisions. Their impact can be broken down into the effects of social learning, social influence (imitation) and social support (social capital) (Montgomery/Casterline 1996; Kohler 2001; Keim et al. 2009; Rossier/Bernardi 2009).

The effects of the deliberately chosen social relationships in a social network are difficult to study because of processes of self-selection, starting with the selectivity of the eligible people. Moreover, we prefer to have close contact with people who share our orientation and our ideas about the way to live, which further promotes self-selection. Therefore, the effects of the social network can only be identified if we have the opportunity to follow the dynamics of social networks closely.

\subsection{A convergent or divergent future?}

So, what will the future hold for sub-national spatial differences in fertility? To begin to answer this question, we must also look back at recent and historical patterns. Watkins (1991) argued that several aspects of the nation-building process contributed to a convergence of regional differences in demographic indicators. One is the establishment of education systems with rather standardised curricula, usually favouring the most prevalent language. This increased the linguistic homogeneity in most of the Western European countries. The standardisation of the curricula probably also contributed to a convergence in social norms with regard to family formation behaviour. The increased linguistic homogeneity supported the establishment of mass media with nationwide reach, which became technically possible 
due to advancements in the transport network and communication technologies (e.g. radio and television) (Basten 2010).

Another important process was the development of national markets and transport networks, which led to a decline in sub-national spatial economic inequalities (Watkins 1991). In addition, many nation-states introduced programs to support regions where development lagged, through which they actively tried to harmonise economic conditions. As demographic behaviour is affected by economic circumstances (Becker 1991), this probably also contributed to convergence of sub-national spatial variation in demographic behaviour. In addition, the introduction of national welfare state institutions, such as the pension system, unemployment insurance schemes or family policies, led to a homogenisation within each nation-state of local conditions for individuals seeking to start a family.

However, in her concluding chapter, Watkins noted that she expects the nationstates of Western Europe to become less important with respect to shaping the demographic map of Europe. She observed that the European integration process, including the creation of the common market of the EU and EFTA countries, is likely to lead to a convergence of economic conditions among countries (e.g. CuadradoRoura 2001). However, it should be pointed out that the European Union, despite being one of the most important supranational bodies in Europe, still has little to say in the area of family policies and other important welfare state institutions, such as the pension system. These are mostly still the sole responsibility of the national governments.

Indeed, despite Watkins' hypotheses, a number of economists and sociologists have suggested that the coming decades will, in fact, be characterised by increased divergence and fragmentation (Veltz 1996; Menze/ 1998; Krätke 1995). Based on empirical economic findings on France, Veltz (1996) developed the hypothesis that the accelerating globalisation process will lead to the development of an "archipelago economy". In this economy, the "global cities" (Sassen 1991) will be the centres of capital accumulation. These centres will be connected by communication corridors, which also benefit from growth effects. This promotes the development of a network pattern of the spatial economic organisation of these societies. Areas that are not part of this network will probably slow down with regard to their development. Veltz also hypothesised that this will occur because nation-states are losing the ability to redistribute resources to areas lagging behind in this process. A related theory by Menze/ (1998) posited that we will see increased societal fragmentation at all geographic levels. Indeed, Menze/ argued that inequality is increasing at the global level, as well as the national and local levels. This theory is supported by urban studies that provide evidence of increased spatial segregation by social status (see Maloutas 2004). It is likely that the emerging divide into regions with shrinking populations, and regions with growing or stable populations, will lead to economic fragmentation processes, as rapid population ageing and decline are very likely to negatively affect regional housing markets and the tax revenues of local and regional authorities.

A final process with potential relevance is sometimes called the "end of geography" (Graham 1998; Cairncross 2001). As recently as in the early $19^{\text {th }}$ century, most 
social interaction was still local in character. This has changed drastically over the last 200 years, due to advancements in transport and communication technologies (Harvey 1990). This process has gained further momentum over the last 20 years due to the creation of the Internet and mobile communication technologies. These communication systems allow people to stay connected and share thoughts, even if they are thousands of kilometres apart. As a result, today it is possible for individuals to maintain a social network stretching over several continents at relatively low costs. This clearly has implications for the analysis of fertility, as local living conditions may lose relevance as an influencing factor of behaviour. But while this trend towards globalised communication might foster further convergence, it is unlikely to lead to an end of spatial differences in the future, as most daily routines still need to be carried out in the real world, where individuals are confronted with geographic distances to artefacts such as infrastructure.

Having considered the theoretical underpinnings with respect to the analysis of the social geography of fertility, we now turn to an examination of the empirical evidence.

\section{Empirical trends in sub-national fertility in Austria, Germany and Switzerland}

Conducting research on sub-national fertility trends in the three predominantly German-speaking countries of Austria, Germany and Switzerland is challenging as we are faced with severe data constraints. In contrast to the Scandinavian countries or the Netherlands and Belgium, no detailed population register data are available. Most of the existing individual-level datasets on Austria, Germany and Switzerland with relevant family formation information are too small to allow us to examine fertility trends on a small geographic scale. Therefore, for this paper we base our empirical analysis on aggregate-level fertility data.

\subsection{Expanding the Eurostat-dataset}

The analyses employed in the Eurostat Regional Reports (e.g. Eurostat 2010a) are necessarily constrained by the need to present a harmonised, continent-wide dataset. These constraints are both temporal, in the use of recent data; and spatial, in the employment of NUTS regions. In this section, we extend the Eurostat analyses in both aspects. First, we employ historical data in order to gauge the extent of convergence over a longer period of time, and to show the historical significance of this change at the regional level. To do this, we combine the latest available data with evidence from the Princeton European Fertility Project and national printed statistical yearbooks. As previously mentioned, however, a universal analysis based on the NUTS-2 level - or, indeed, on the NUTS- 1 or NUTS-3 levels - may miss many important cultural, social and economic factors which play key roles in shaping the social 
geography of fertility. Therefore, we expand (or limit) the Eurostat report spatially by conducting a case study with fine geographic detail.

\subsection{Data sources}

Creating long historical time series of fertility rates for given regions is fraught with difficulties. One of the problems relates to the spatial consistency of the regions over time. In attempting to construct as long a time series as possible, we have sought to identify regional level differences in fertility stretching back to the mid-19th century. However, it goes without saying that the period 1860-2010 saw German-speaking countries altered and shifted to a hitherto unheard of degree. The formation of the German Nation-state, and the rise and fall of Austria-Hungary, National Socialism and the GDR each played a role in shaping the sub-national regions which made up their ever-shifting borders. Fortunately, however, the Bundes/änder of Austria and the cantons of Switzerland have stayed relatively constant over time. The rather more turbulent nature of Germany's borders will be examined shortly.

Any attempt to compile regional fertility data for the past 150 years will necessarily require the pulling together of a patchwork of very different data sources. The data sources and definitions are presented in Table 1 below, and discussed in greater depth thereafter. Whenever possible, we have attempted to remodel the historical data into the equivalent NUTS boundaries. Of course, this exercise requires a degree of geographical licence, and there will inevitably be some highly problematic cases, such as the inclusion of Vienna in Lower Austria in the pre-1930 data. However, for the purposes of this analysis, we seek to identify patterns of changes within a broadly defined set of boundaries over time. Therefore, rather than providing a continuous time series, we distinguish different time periods in which we can draw upon comparable data, both in terms of the regional set-up and in how the data was derived (see Table 1 for details). These time periods should be viewed as a discrete set of observations, and only a provisional view of the relative range and degree of convergence or divergence over time should be taken.

\section{Period y}

Period $y$ covers the pre-1960 era for all of the three countries, and is examined using data collected as part of the Princeton European Fertility Project (PEFP). The PEFP was a path-breaking attempt to gather and analyse a wide set of demographic data relating to European fertility at the regional level over the 19th century, and up to 1960. Despite having been the object of considerable criticism (e.g. Galloway et al. 1994; Brown/Guinnane 2007), the Princeton dataset defined much of the European historical demography for the period 1850-1960, and has served as the basis for two of the most influential books of the history of European provincial fertility (Coale) Watkins 1986; Watkins 1991).

The project verified the presence of significant spatial differences in fertility across Europe during the last two centuries up to the 1960s, and discussed the reasons for these disparities (Anderson 1986; Coale/Treadway 1986). A main find- 
584 - Stuart Basten, Johannes Huinink, Sebastian Klüsener

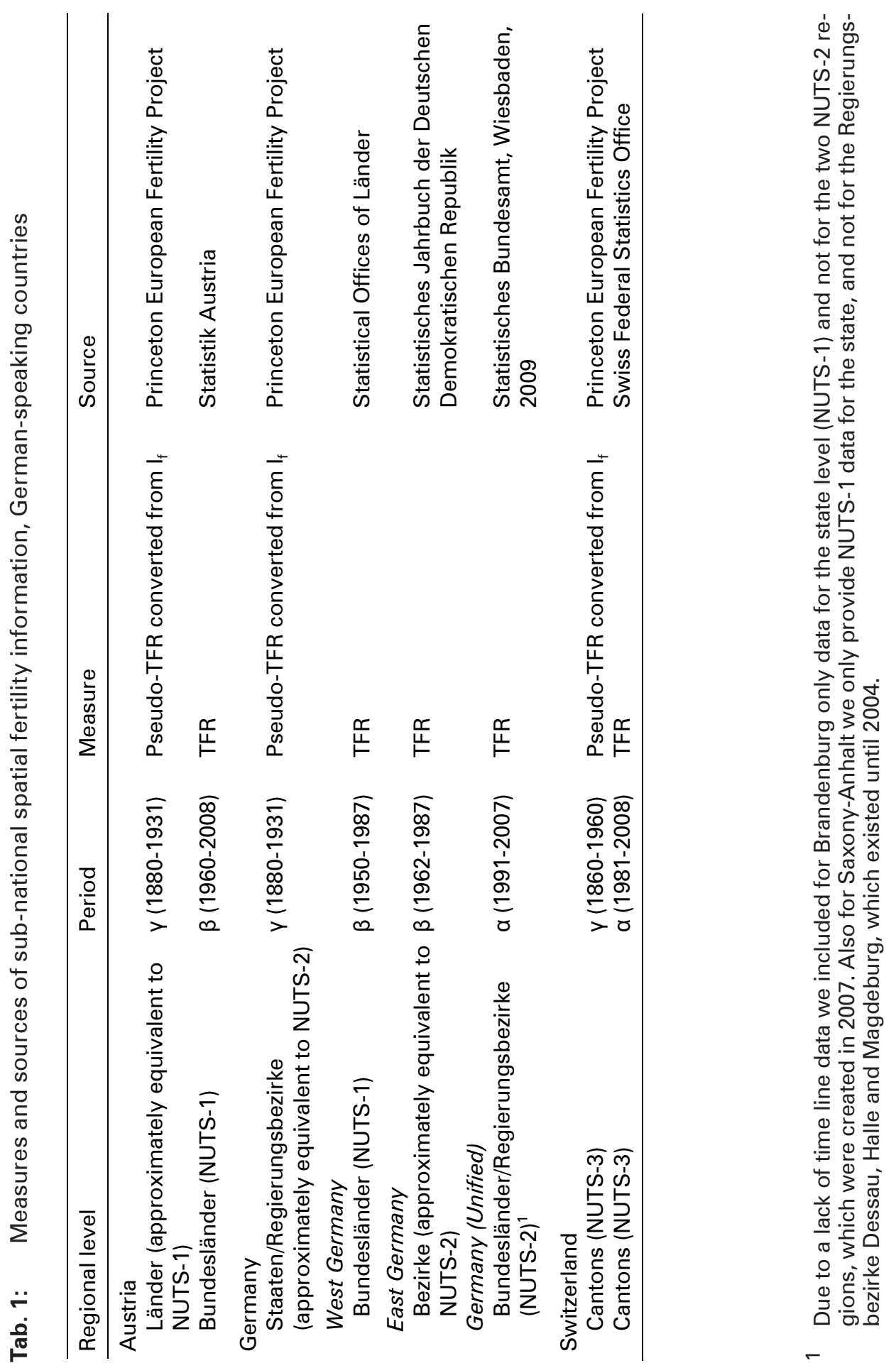


ing was that spatial differences in Europe are persistent over time, but had become somewhat smaller during the first demographic transition. The marital behaviour played an important role, but cannot entirely explain these regional variations. For example, particularly in the early and middle phases of the first demographic transition (1900), there were large differences in marital fertility between the provinces in some countries, but variations in the proportion of married couples was also responsible for differences in the overall fertility in many other countries.

While data relating to marital fertility are available for period $\mathrm{y}($ as $\mathrm{I} g$ ), we chose to employ the overall index of fertility $\left(I_{f}\right)$, as it removes one extra layer of assumptions regarding these estimates. Second, the output of the PEFP was the development of a ratio of the number of births of women in a given region and calendar year in relation to the number of births given the Hutterite standard of uncontrolled fertility. A simple procedure, described by Sardon (1996), can be followed to convert this ratio to something similar to the total fertility rate (TFR). For the conversion to be meaningful, the following equality must first be supposed:

$$
\frac{B_{O B S}}{B_{H U T}}=\frac{T F R_{O B S}}{T F R_{H U T}}
$$

where:

$B_{O B S}=$ number of births observed in the population studied

$B_{\text {HUT }}=$ number of births in the population studied with the Hutterite family schedule. hence:

$$
\frac{\sum_{i} F_{i}^{n} f_{i}^{n}}{\sum_{i} F_{i}^{n} h_{i}^{n}}=\frac{\sum_{i} f_{i}^{n}}{\sum_{i} h_{i}}
$$

where:

$F_{i}^{n}=$ population of women aged $i$ in year $n$

$f_{i}^{n}=$ fertility rate at age $i$ in year $n$

$h_{i}=$ Hutterite fertility rate at age $i$

This expresses the fact that "the relation between the observed number of births and the number expected if the Hutterite fertility rates are applied is equal to the equivalent relation between observed and Hutterite fertility rates" (Sardon 1996: 253). It therefore follows that

$$
T F R_{O B S}=\left(\frac{B_{O B S}}{B_{H U T}}\right) \times T F R_{H U T}=I_{f} \times T F R_{H U T}
$$

or, one can multiply the $I_{f}$ by the Hutterite TFR of 12.44 in order to find the TFR of the population observed. Sardon's paper tested the veracity of this process by reestimating observed TFRs using this method and found the results to be "not bad" (257). 


\section{Period $\beta$}

For East Germany, we were able to supplement the PEFP and recent data by extracting fertility rates from published Statistical Yearbooks. We obtained the TFR rate at the Bezirk level for the period 1962-1987. For West Germany, we contacted individual statistical offices, of which many were able to produce long-run datasets of TFR. Thanks to the efforts of Statistik Austria and the Vienna Institute of Demography, we were able to secure a series of TFRs for Austria at the Bundes/and level for the period 1960-2008. We have inserted an individual point estimate made for Vienna in 1951 (Gisser 1975). For Switzerland, we were unfortunately not able to obtain adequate data at the canton level for this period.

\section{Period $\alpha$}

For this final period, we were able to access TFRs published by national statistical offices and Eurostat. While the period TFR has been rightly criticised as a misleading measure in recent times (Sobotka/Lutz 2009), it is still the foundation of our modern measurement of fertility. As such, this is the measure which both individual statistical offices and Eurostat use as the basis for delivering information on regional-level fertility. The more general issues regarding the fertility data quality for the modern period are examined in greater depth in Kreyenfeld et al. (2011 in CPoS 36,2-3).

It is clear, therefore, that the data employed in the time periods $\alpha, \beta$ and $y$, respectively, are very different from each other in respect to the spatial integrity, nature and form of the data. As the goal of this exercise is to examine the relative differences in regional fertility rates at given points in time, we have decided not to try and force these three disparate datasets into one continuous time series. Instead, we will examine each dataset as a reflection of a discrete period in time. After taking into account the various inadequacies of each of the datasets - especially the possible errors in estimation in period y and the period-quantum effects (Sobotka) Lutz 2009), which would be particularly prevalent in period $\alpha$ - we can attempt to observe some historical patterns over time, which may enhance our understanding of contemporary differences.

\subsection{Measuring convergence over time}

Convergence of the variation of an attribute over time can be measured in a variety of ways, but the most standard measure is to gauge the $\sigma$-convergence, or overall convergence, while accounting for the fluctuating mean. In order to test for $\sigma$-convergence in this paper, we have used the measure of coefficient of variation $\left(C_{v}\right)$, which has also been employed in other studies of regional change in fertility (e.g. Coleman 1993). This is calculated as

$$
C_{v}=\frac{\sigma}{\mu}
$$


which is the standard deviation divided by the mean: if complete homogeneity is achieved, then $C_{V}=0$. This measure has been used because it represents the simplest way to account for the fluctuation of the mean.

There are benefits and drawbacks when using this particular measure. On the positive side, the $C_{V}$ measure ignores fluctuating means by treating each sequential period observation as entirely independent. However, during the course of fertility transition, it is of course highly likely that these temporally juxtaposed observations of any region $\mathrm{k}$ are in fact related, given the effect of the timing of the onset of decline on its trajectory. Despite this problem, we believe that $C_{V}$ still offers a useful way to present a mainly descriptive account of spatial fertility variability over a long period of time.

\subsection{Austria}

The Austrian dataset is unusual in that it broadly maintains the spatial integrity of the Bundes/änder over time, although it should be noted that the pre-1930 data for Lower Austria include Vienna, and that data for Burgenland are not available until 1960. In terms of convergence, the inclusion of Vienna in Lower Austria potentially masks an important outlier in the $19^{\text {th }}$ century. In general, we can distinguish three periods in the development of the $C_{v}$. A period of little change prior to the onset of the first demographic transition is followed by an era with quite substantial divergence lasting until the period around World War I. Since then, there has been a striking degree of convergence over the past five decades. Indeed, there appears to be clear evidence of convergence upon the Viennese rates.

The history of the regional characteristics of Austrian fertility using the PEFP data has been described by Paul Demeny and as part of the Graz Austrian Fertility Project (Demeny 1968; GAFP 2010), as well as in a recent PhD thesis (Gude 2010). Historically, of course, separating Austria from its wider imperial context can be quite difficult. Indeed, the Austro-Hungarian Empire was located to both the east and the west of the so-called "Hajnal line" which demarcated the "European marriage pattern" (Hajnal 1965). With regard to this demarcation, it is important to note that particularly Vienna and Lower Austria received substantial in-migration from the eastern territories of the Austro-Hungarian empire in the late $19^{\text {th }}$ and early $20^{\text {th }}$ centuries. Contemporary Austria is, however far smaller, and more homogenous. Furthermore, the social policy framework of Austria is generally determined in Vienna, rather than at the sub-national level of the federal states.

Despite this, a number of important and distinct patterns emerge. In particular, the extraordinarily low fertility of the city of Vienna in the 1930s is notable, with the number of women aged 25 to 30 being more than three times larger than the number of girls aged zero to five. Indeed, the Viennese TFR in 1934 was just 0.606 (Lutz/Hanika 1989), rising only to 1.11 by 1951 (Gisser 1975).

The trajectory of post-WWII Viennese fertility is, however, particularly interesting. From the 1960s onwards, fertility in Vienna was much lower than in the rest of Austria, until the other federal states of the country broadly converged at the capital's levels from the mid-1980s to the present day. It is worth now to consider 
Fig. 1: Sub-national fertility variation in Austria 1880-2009, NUTS-2

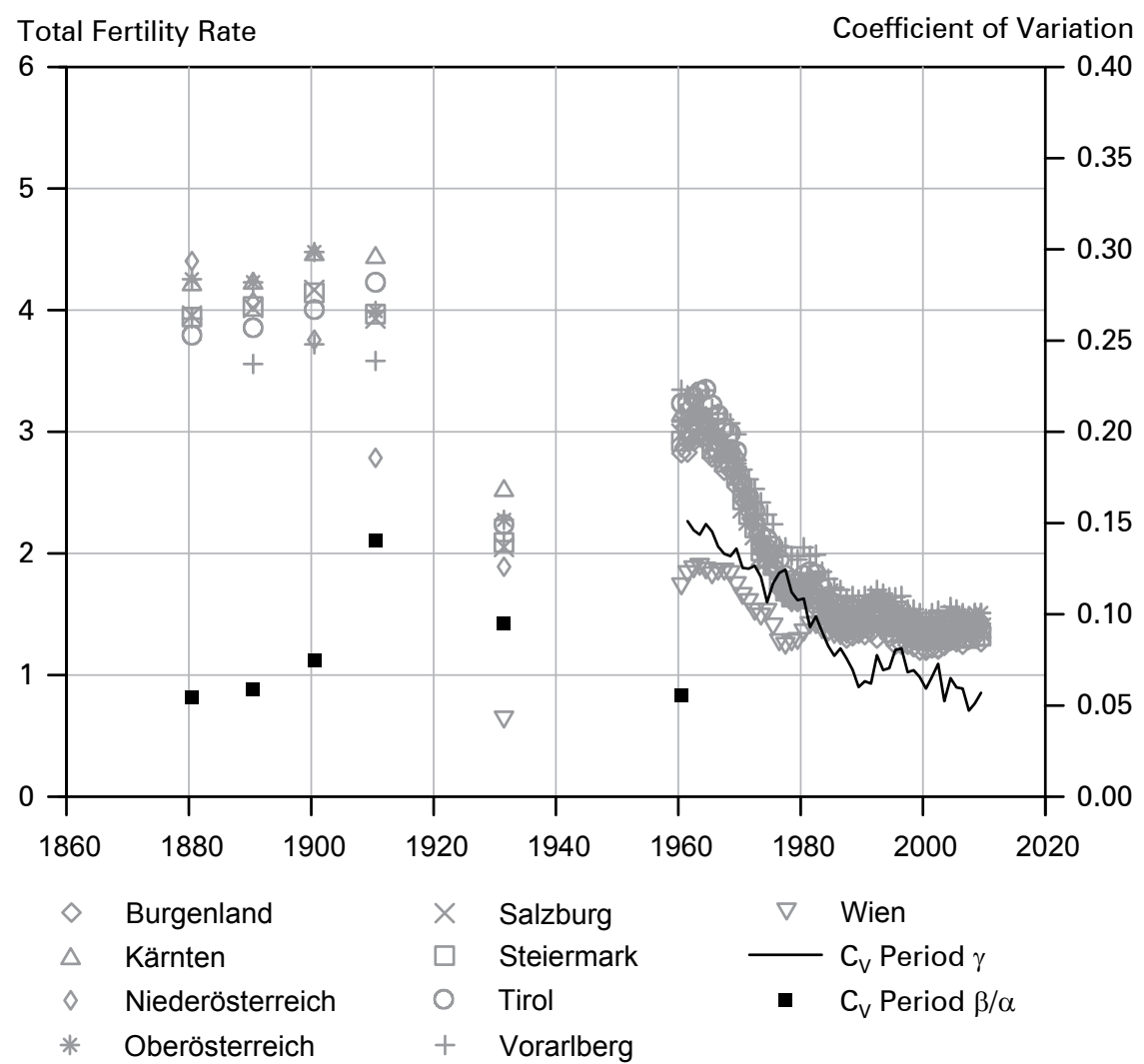

Notes: For $C_{V}$ figures, see Appendix III.

Source: Princeton European Fertility Project; Vienna Institute of Demography/Statistik Austria

the relationship between the Viennese and other regional fertility rates over the past few decades. In 1987, Burgenland became the first federal state to report a lower TFR than Vienna. Indeed, if we focus on the period after this change, we can see that Burgenland consistently reports the lowest fertility in the country, and that especially in the post-2000 era, Vienna's fertility rates have been undercut by other federal states, notably Styria and Carinthia. In 2003, Vienna reported the second highest fertility rate of all Austrian federal states. However, a more in-depth analysis of the characteristics of fertility in Vienna is made possible by the city's Geburtenbarometer, which shows the important effect of international migration. Indeed, Zeman calculated that migrant women in Vienna have contributed around 0.3 to the city's TFR in absolute terms between 2002 and 2008. For the rest of the country, the net contribution of migrants was just 0.12 in 2008 (Zeman 2010). Taking into account our theoretical discussion mentioned above, however, we might also suggest that the improved material infrastructure for families in Vienna may have had an impact on fertility. 


\subsection{Germany}

In the case of Germany, we were faced with particularly severe data constraints. While for the period prior to 1945, data at the state level and the Regierungsbezirk level ( NUTS-2 level) can be obtained from the Princeton Fertility Project, data are particularly scarce for West Germany between World War II and 1989. For East Germany, we have data for the Bezirke ( NUTS-2 level), while for West Germany we could only derive data at the NUTS-1 level. For the period from 1991 onwards, we were again able to use detailed NUTS-2 level data at the levels of Regierungsbezirke and the small federal states. With respect to the last 60 years, this section on Germany will mainly focus on differences between East and West Germany, while a more detailed look at factors of regional fertility differences will be provided in the case study on Lower Saxony and Bremen.

Like Austria and Switzerland, Germany has experienced quite a substantial divergence trend in spatial fertility variation in the early period of the first demographic transition (see Fig. 2). As rural, and particularly rural Catholic, areas tended to lag behind in this process, at least temporarily, the differences increased along the axes denoting the degree of urbanisation and the share of Catholics (see K/üsener/Goldstein 2012). This can also be seen in Appendix II, where the cities of Berlin, Hamburg and Bremen, as well as the highly urbanised and secularised state of Saxony, were pioneering this process; while predominantly rural areas, such as Bavaria or the western part of Lower Saxony (Oldenburg/Osnabrück) lagged behind. The process culminated in the 1930s, when similarly to Vienna, the big cities reported TFRs well below sub-replacement levels.

The following decades were characterised by a kind of rollercoaster pattern in the period fertility rates (particularly in East Germany). The cohort fertility rates, on the other hand, remained rather stable at around 1.8 for the East German cohort born between 1945 and 1960, while West Germany experienced a decrease to levels of around 1.6 (MPIDR/VID 2010). The increase of the 1930s occurred parallel to the introduction of pro-natalist policies by the Nazi regime (Pine 1997). After a sharp decline caused by the war, the period TFR increased again in the 1950s, when even Berlin reported levels of around 2.0. Unfortunately, due to data scarcity, we are not able to calculate the $C_{V}$ for this period.

In both parts of Germany, the late 1960s and early 1970s were characterised by another sharp fertility decline with surprisingly few differences in the temporal trajectories of the West and East German regions. The decline took place within a period of ten years, while in the late $19^{\text {th }}$ century, the onset of the fertility decline lagged by more than two decades in some regions. From the 1970s onwards, the period fertility rates stabilised in West Germany, while East Germany experienced another period with a sharp fertility increase. Buttner and Lutz (1990) provided empirical evidence that this can be mainly attributed to pro-natalist family policies, which were enacted in the GDR in the late 1970s. This led to a substantial divergence of TFRs between West and East Germany, while within the two states, regional values converged. But the increase observed in East Germany was short-lived, and was followed by a sharp decline in the transition crises in the 1990s, which partly even 
Fig. 2: $\quad C_{v}-$ Sub-national fertility variation in Germany 1867-1933, PEFT provinces (excluding territories East of Oder-Neiße-border)

Coefficient of Variation

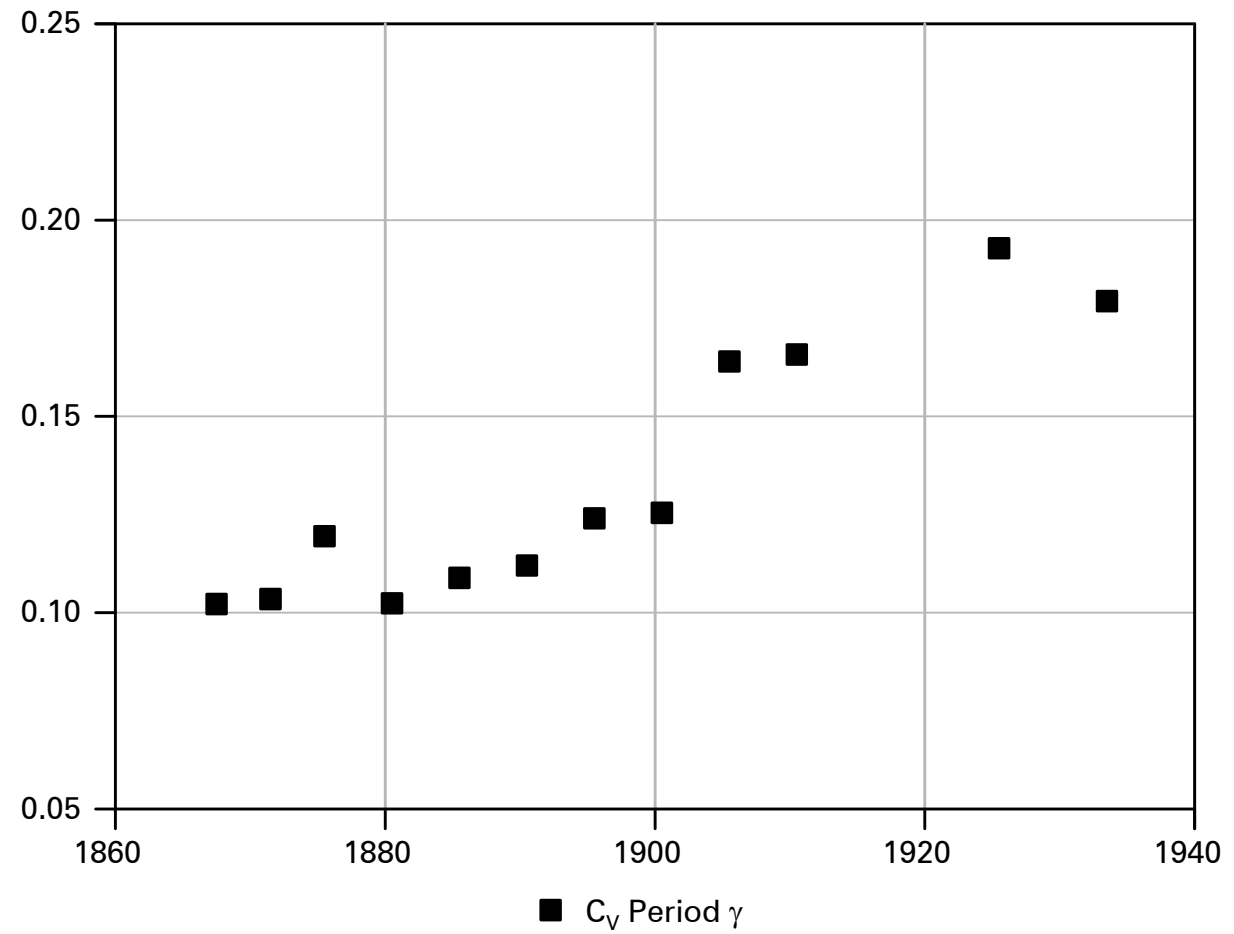

Notes: For $C_{V}$ figures, see Appendix III.

Source: Princeton European Fertility Project

affected cohort fertility rates. This again led to a divergence of West and East Germany.

Owing to missing data in Period $\beta$, we were only able to calculate a meaningful $C_{V}$ measure within East and West Germany for the period 1970-1987. In Figure 3, we can observe that the $C_{V}$ was greater in West Germany, and that, hence, the country was more regionally heterogeneous than East Germany.

In recent years, period fertility differences between Eastern and Western Germany have converged again, but some researchers (Goldstein/Kreyenfeld 2011) believe that we will see another divergence trend in the future. This assumption is based on the expectation that East German TFRs are likely to increase to higher levels than those in Western Germany over the medium term. This expectation is based on two observations: First, East German attitudes to family formation are much less traditional than those of West Germans, which can be seen, for example, when considering the high number of births outside marriage (Klüsener/Kreyenfeld 2009). Additionally, access to child care is much better in Eastern Germany than in Western Germany. 
Fig. 3: Sub-national fertility variation in Germany 1950-2008, NUTS-1 (West Germany in grey, East Germany in light grey)

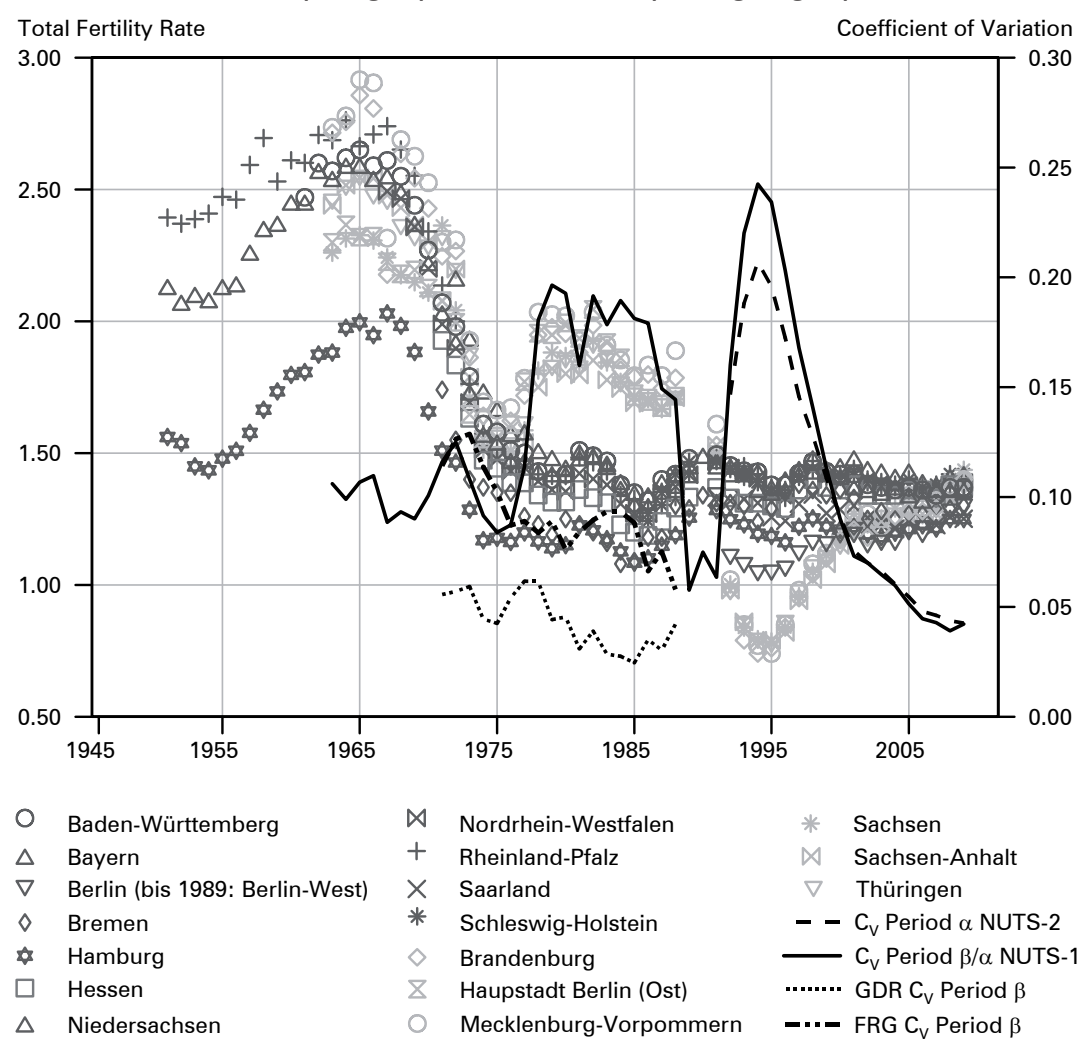

Notes: East German Bezirke have been aggregated to their equivalent NUTS-1 region. For $\mathrm{C}_{\mathrm{v}}$ figures, see Appendix III.

Source: West Germany - Statistische Landesämter; East Germany - Statistisches Jahrbuch der DDR; Germany since 1991 - Statistisches Bundesamt

\subsection{Switzerland}

In contrast to Germany and Austria, regional identities in Switzerland are rather anchored at the NUTS-3 level, which comprises the Swiss cantons. This is also important because policy distinctions are made at the cantonal level.

Figure 4 shows the sub-national patterns of fertility in Switzerland at the NUTS-3 level from the mid-19th century to the present day. In Period y, the lowest fertility can be found in the primarily urban cantons of Geneva, Basel, Neuchatel and Zurich. In 1920, for example, while Basel-Stadt saw a nominal TFR of 1.3, the surrounding canton of Basel-Landschaft had a fertility rate that was almost twice as high. High fertility appears to be concentrated in Appenzell-Ausserrhoden and AppenzellInnerrhoden, Nidwalden, Uri and Obwalden; i.e. an area concentrated around the centre and the east of the country. Lesthaeghe and Wilson observed that, as in 
many other European countries, the decline of marital fertility in Switzerland during the period 1860-1920 can, at least in part, be associated with household economic circumstances and secularisation (Lesthaeghe/Wilson 1986).

With regard to divergence and convergence, the Swiss dataset is particularly interesting, as it is the longest time series available to us. The data go back to 1850 . Figure 4 shows that in the period prior to the first demographic transition, a convergence process took place within the country. With the onset of fertility decline, the rates diverged, as urban areas again experienced the decline first, reaching the highest levels in the 1920s and 1930s. Since then, the rates have again converged, with a very significant level of convergence occurring in recent decades. As well as identifying $\sigma$-convergence, we can also identify $\beta$-convergence, with the sharpest drops seen in areas of high fertility in 1980, while cantons with a low fertility in 1980 have either remained stable, or experienced a slightly increasing fertility rate.

In order to better understand these variations in fertility, we need to examine the similarities and differences between cantons. Cantons share broadly similar living conditions; there are no labour market barriers between them, and federal law regulates many aspects of the daily life. Indeed, it has been argued that the cultural and religious diversity of the country no longer has a strong impact on fertility (Wanner 2004). There are, however, very striking differences in terms of employment, particularly agricultural employment. In Appenzell-Innerhoden, for example, over $20 \%$ of the population was active in agricultural employment in 2001, compared to almost none in Basel-Stadt and Zurich. Furthermore, differential fertility between native and immigrant populations, as identified by Wanner, plays an important role in shaping the fertility landscape of some cantons, particularly urban ones (Wanner 2002).

Finally, a number of studies have identified the significant difference in family policies between cantons (Vatter 2002; Armingeon et al. 2004), and how these might be linked to differential fertility (Bonoli 2008). Indeed, the monthly amount of a standard child benefit varies between 150 and 300 Swiss francs, depending on the canton of residence, and similar differences can be seen when comparing the extent of childcare services. Especially, Catholic cantons tend to have the most generous family benefits, but invest fewer resources in childcare. Meanwhile, Armingeon et al. (2004) found that the relative strength of the left in cantonal politics was associated with both more generous family benefits and better child care services.

A regression analysis by Bonoli proved that there is an interaction of a number of different factors in different cantons. First, the process of de-agrarianisation is very important. Second, Bonoli suggested that the presence of day care centres, which are mainly concentrated in the urban cantons, may have played a role in keeping fertility rates in these areas stable between 1980 and 2000. Finally, the study found a moderate but statistically significant effect of the level of family benefits on fertility by canton. This echoes not only the theoretical section above, but also other studies, particularly from Spain (Baizán 2009) and Norway (Kravdal 1996).

Bonoli (2008: 74) concluded: "Both old and new determinants seem to be playing a role simultaneously in explaining change in fertility. On the one hand, societal modernisation, measured with the decline in agricultural employment, is a statisti- 
Fig. 4: Sub-national fertility in Switzerland 1860-2008, NUTS-3

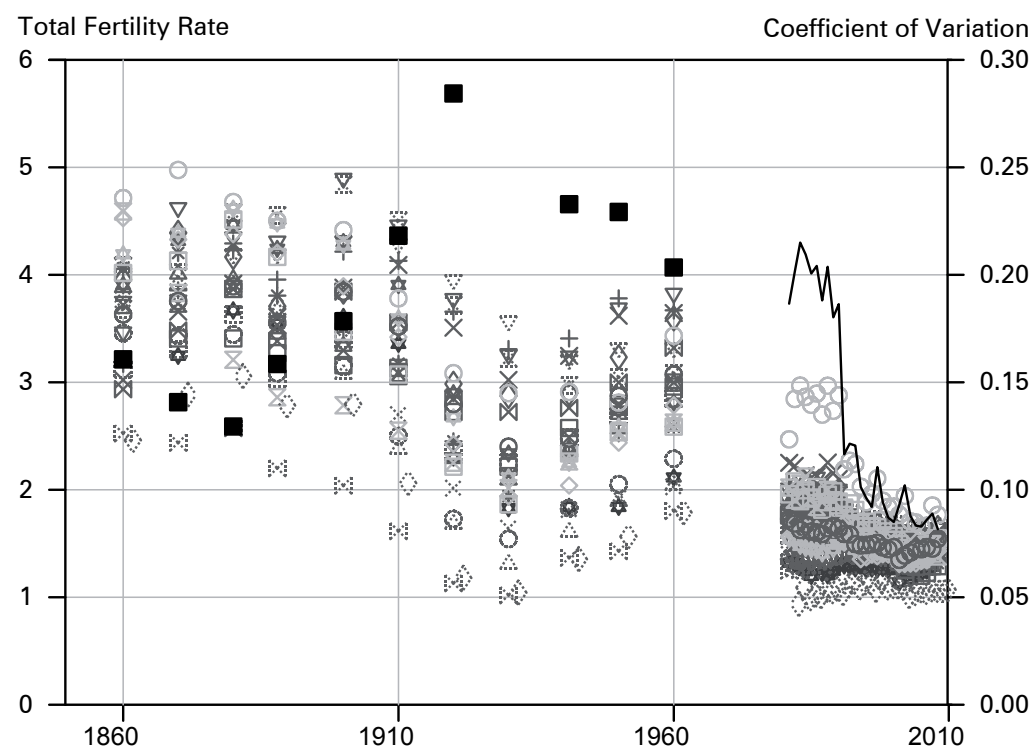
(G) Aargau
$+\quad(G)$ Nidwalden
(G) Zurich
(G) Appenzell Ausserrhoden
(G) Obwalden
(F) Fribourg
(G) Appenzell Innerrhoden
(G) Schaffhausen
(F) Geneve
(G) Basel-Landschaft
(G) Schwyz
(F) Neuchatel
(G) Basel-Stadt
(G) Solothurn
(F) Valais
(G) Bern
(G) St. Gallen
(F) Vaud
(G) Glarus
(G) Thurgau
- (I) Ticino
(G) Graubünden
(G) Uri
- $\mathrm{C}_{\mathrm{V}}$ Period $\gamma$
(G) Luzern
(G) Zug
$\mathrm{C}_{\mathrm{V}}$ Period $\alpha$
(G) = German
$(\mathrm{F})=$ French
(I) = Italian

Notes: For $C_{V}$ figures, see Appendix III.

Source: Swiss Federal Statistics Office, Princeton European Fertility Project data

cally significant predictor in all models. On the other hand, the new determinants, child care availability and the generosity of child benefits, remain significant predictors even after controlling for the effect of societal modernisation". Of course, Bonoli is quite right to point out that "[f]ertility decisions are unlikely to be the result of rational calculations where a few Swiss francs variation in family benefits can be important"; and that the family policies, together with "a general policy climate that is more favourable to the reconciliation of work and family life", play crucial roles Bonoli (2008: 74). 


\subsection{Convergence?}

The evidence presented above strongly suggests that convergence is the dominant theme of sub-national fertility over recent decades, particularly when examined at the various NUTS levels. Table 2 shows 18 European countries with more than five NUTS-2 regions and the available data for comparing the $C_{V}$ in the early 1990 s with the latest data (2004-2008). Over this period, fertility differences between NUTS-2 regions, at least measured by the $\mathrm{C}_{v^{\prime}}$, have decreased in 15 of the 18 countries.

However, as we have already shown, none of the NUTS levels is an appropriate level for considering the effects of both cultural and policy differences on fertility in all countries. Significant differences do still exist, and if we are to move beyond what Sobotka (2002) calls "substantively empty mechanistic views of fertility change" in order to "try to obtain interdisciplinary and theory-driven explanations", it is necessary to develop a more nuanced and less universalist approach (208). This may, as we have seen, mean examining the different sources of data in different ways for different countries.

Tab. 2: Comparing Cv for sub-national TFRs in 18 European Countries, NUTS-2

\begin{tabular}{llll}
\hline$C_{v}$ 1991-1995 & & $C_{v}$ 2004-2008 & \\
\hline 18 countries (unweighted) & 0.199 & Spain & 0.124 \\
Germany & 0.183 & Portugal & 0.118 \\
Italy & 0.167 & Bulgaria & 0.111 \\
Spain & 0.162 & Greece & 0.104 \\
Portugal & 0.138 & Finland & 0.098 \\
Czech Republic & 0.136 & Italy & 0.097 \\
Bulgaria & 0.135 & 18 countries (unweighted) & 0.088 \\
Poland & 0.126 & Czech Republic & 0.086 \\
Hungary & 0.101 & Belgium & 0.085 \\
Switzerland & 0.093 & Poland & 0.081 \\
Sweden & 0.088 & Netherlands & 0.078 \\
Netherlands & 0.085 & Hungary & 0.075 \\
France & 0.078 & France & 0.067 \\
Belgium & 0.075 & Denmark & 0.062 \\
Norway & 0.074 & Switzerland & 0.058 \\
Greece & 0.074 & Norway & 0.057 \\
Finland & 0.073 & Austria & 0.056 \\
Austria & 0.072 & Germany & 0.049 \\
Denmark & 0.057 & Sweden & 0.042 \\
\hline
\end{tabular}

Notes: Only countries with at least 5 NUTS-2 regions included.

Source: Eurostat, Statistical Offices, MPIDR Rostock 


\subsection{Divergence within Convergence - Contrasting the City of Bremen and the State of Lower Saxony}

The preceding section has shown that the sub-national fertility trends at the macro-regional level in Austria, (West and East) Germany and Switzerland have been characterised by a process of convergence in recent decades. In this section, we will turn to an exemplary analysis of more detailed geographic data, which will illustrate that the observation of convergence does not necessarily hold at a lower geographic level.

The study area of Lower Saxony and the city of Bremen comprises 8.5 million people, or around 1/10th of the German population. This is comparable to the populations of Austria (8.4 million) and Switzerland (7.8 million). Both for Lower Saxony and Bremen, we have TFR data available for the period 1971-2006 on a small geographic scale. This area of Germany is of particular interest, as it exhibits the highest diversity in regional fertility levels, at least in Western Germany. The western part of Lower Saxony (areas around Oldenburg and Osnabrück) which borders the Netherlands has reported the highest period TFRs in Germany for decades (see also Appendix I). In the beginning of the 1970s, many municipalities had rates above 3.0, while today's levels are 1.6-1.8 - which is well above the German average. The area is rather rural and predominantly Catholic. The eastern part of the state (e.g. areas around Hannover and Braunschweig), meanwhile, saw period fertility levels below replacement level in the 1920s (see Appendix II). Today, that area is among the Western German regions with the lowest fertility levels and the highest old-age dependency ratios.

The principal unit of investigation for Bremen are the city districts, while for Lower Saxony it is the municipalities and unified rural communities (Samtgemeinden). In order to have at least 1,500 females of reproductive age in each of the units during the whole study period, some smaller units have been amalgamated, while some larger units have been subdivided based on a set of rules (see Klüsener 2009 for details). In addition, some problematic units were excluded from the analysis. In total, for Bremen we have data for 28 units, while Lower Saxony is subdivided into 255 units. The geographic extent of each observed unit is time-constant over the period studied.

We first contrast the $C_{V}$ development of the local TFRs of Lower Saxony and Bremen, which is displayed in Figure 5. The figure for Lower Saxony shows a very similar pattern to that observed for the NUTS regions of Austria, Switzerland and both West and East Germany. Since the mid-1970s, the values have converged, with the line being particularly steep in the period 1986-1988. This was a time in which the period TFR of many big urban areas saw substantial increases, while the levels of rural areas continued to decrease. The family policy reform of 1986 might have played a role in this trend (Klüsener 2009).

Within the city of Bremen, on the other hand, we can observe a divergence trend since the mid-1970s. Klüsener (2009) identified three main mechanisms which fostered this trend. All are at least partly connected to selective migration and spatial segregation processes. The first is a long-lasting structural economic crisis, which 
Fig. 5: Divergence within convergence: $C_{v}$ in Lower Saxony and Bremen Coefficient of Variation

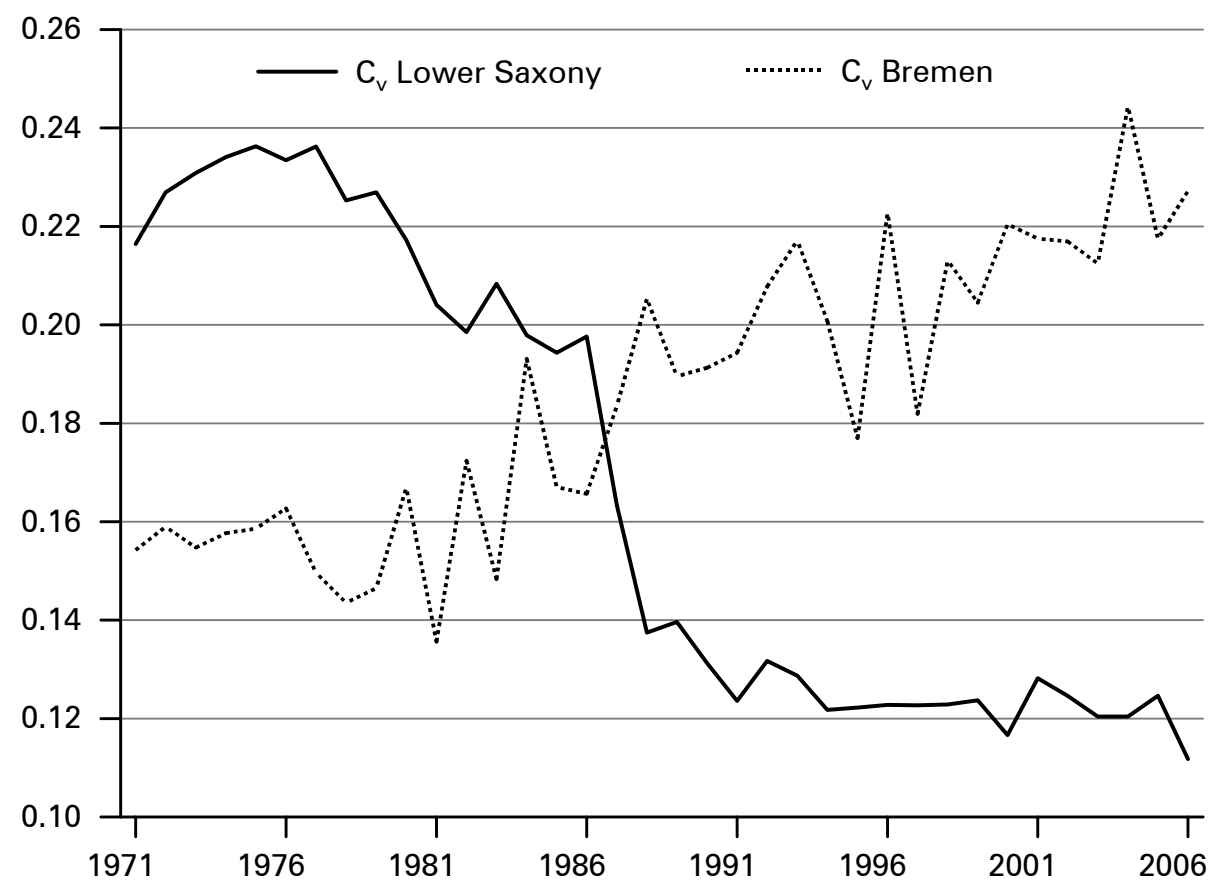

Source: Statistical Offices of Lower Saxony and Bremen, own calculations

started in the 1970s and has not yet been overcome. As a result, quite substantial pockets of economically deprived actors can be found today in the working-class districts of the city. The second is a dramatic expansion of the tertiary education institutions, which led to an increase in the number of students studying at tertiary institutions, from 3,000 in 1970 to almost 30,000 in 2006. This influx of students led to tremendous social changes, particularly in those districts close to the tertiary education institutions. The third is a paradigm change in housing preferences, which resulted in a gentrification process in the city districts around the city centre. Today, several "gentrified academic" districts of the city of Bremen report TFR levels well below 1.0, while in other districts we observe levels above 1.6. It would be interesting to investigate whether these local "hot spots" of period lowest low fertility have a contextual impact on the fertility decisions of actors who have spent at least parts of their lives in these areas. 
For Lower Saxony, we also have a number of structural variables available which might influence fertility levels. ${ }^{2}$ This allows for an examination of potential associations between fertility trends and these structural variables. In an effort to avoid ecological fallacies, we do not simply interpret these associations to hold at the individual level. ${ }^{3}$ Moreover, we will also refrain from setting up sophisticated models because of the limited time-series data availability. An introduction to spatial panel modelling techniques would also go beyond the scope of this paper. We will therefore focus on descriptive findings, and point out potential challenges of attempts to implement causal modelling of the processes observed.

First, we will examine whether the convergence pattern observed in the fertility development can also be observed in the structural factors which we have available (see Fig. 6). Among these indicators, "child care" and a longer time series with unemployment data are only available at the district level. The child care data were only available for 1986, 1994, 1998 and 2002, so these data were interpolated.

With regard to the economic indicators, these appear to have remained rather stable over time, with exceptions being the share of employees in the industry and the local unemployment levels, which have registered a divergent trend since the mid-1990s. The graphs give no indication that there is a strong relationship between economic divergence and convergence trends and the convergence trend of the TFR. The same is true for population density (this variable has been log-transformed, as it is highly left-skewed).

While a substantial convergence trend can be observed in the child care variable, it is very questionable whether a causal link between convergence in child care and the convergence in fertility levels could be easily established. One major challenge is illustrated in Figure 7, which shows the rather unusual positive ecological association between TFR levels and child care coverage for 1986. But this pattern did not hold for long. By 2001, it had changed to the more common picture of a strong negative ecological association. In our opinion, the pattern of 1986 is largely an artefact created by local planning institutions. In recent decades, the expansion of child care did not follow the principle that child care should be developed in those areas where the demand for child care was highest. Planning was in the responsibility of the local administration, and little strategic planning took place, at least until the early 1990s (Jaich 2003). It was usually either based on the number of children in the respective age groups, or on the number of births observed, which provided a rough estimate of the short-term future demand.

2 A more detailed discussion of the Bremen case can be found in Klüsener 2009.

3

An "ecological fallacy" is a potential error in the interpretation of statistical data in an ecological study, whereby inferences about the nature of specific individuals are based solely upon mean values for the groups to which those individuals belong. If such groups display high internal heterogeneity in the variation of the attributes of interest, such an inference might not hold at the individual level. However, in spatial analysis, the risk of making an ecological fallacy error is dependent on the size of the region, as populations become usually more homogenous, the smaller the unit of observation (Carstairs 1981). 
Fig. 6: Lower Saxony: $C_{v}$ of developing structural factors Coefficient of Variation

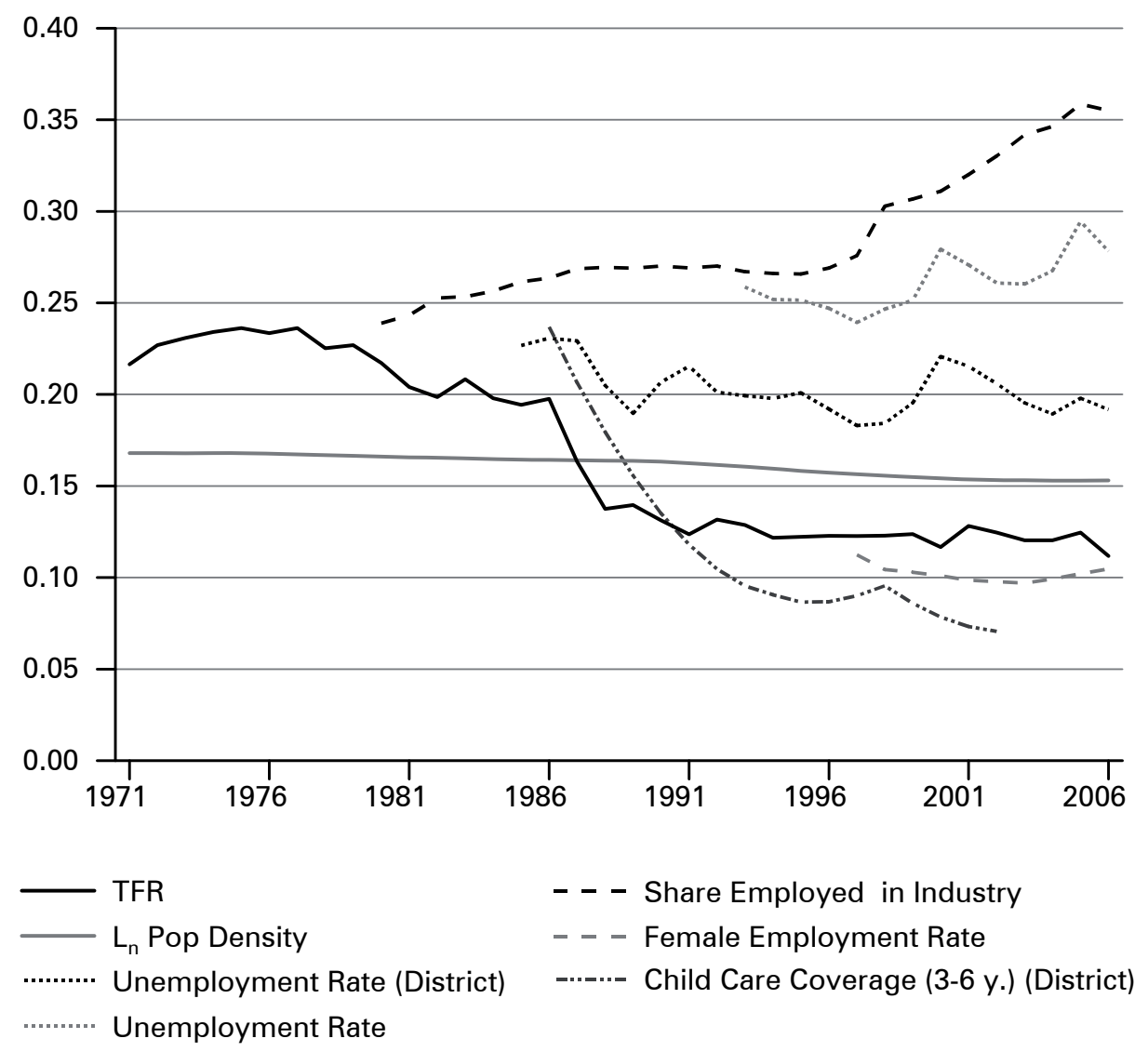

Source: Statistical Offices of Lower Saxony and Germany, own calculations

As there usually is a lag of several years between local planning activities and the construction and opening of child care institutions, the coverage is to some extent influenced by the fertility levels that existed some years earlier. As a consequence, in periods of rapid expansion, such as the 1970s and 1980s, this impact is likely to be higher in those areas where the fertility decline occurred later, while it is likely to be lower in areas which had already reached a low fertility level. As a result, child care coverage is associated with lagging fertility changes (see the second graph on the left column of Fig. 7), which is likely to cause endogeneity challenges in any causal analyses.

In order to examine the association between economic trends and fertility levels (see Section 2.2) we will study the ecological relationship between unemployment 
Fig. 7: Child care coverage and TFR (Lower Saxony)
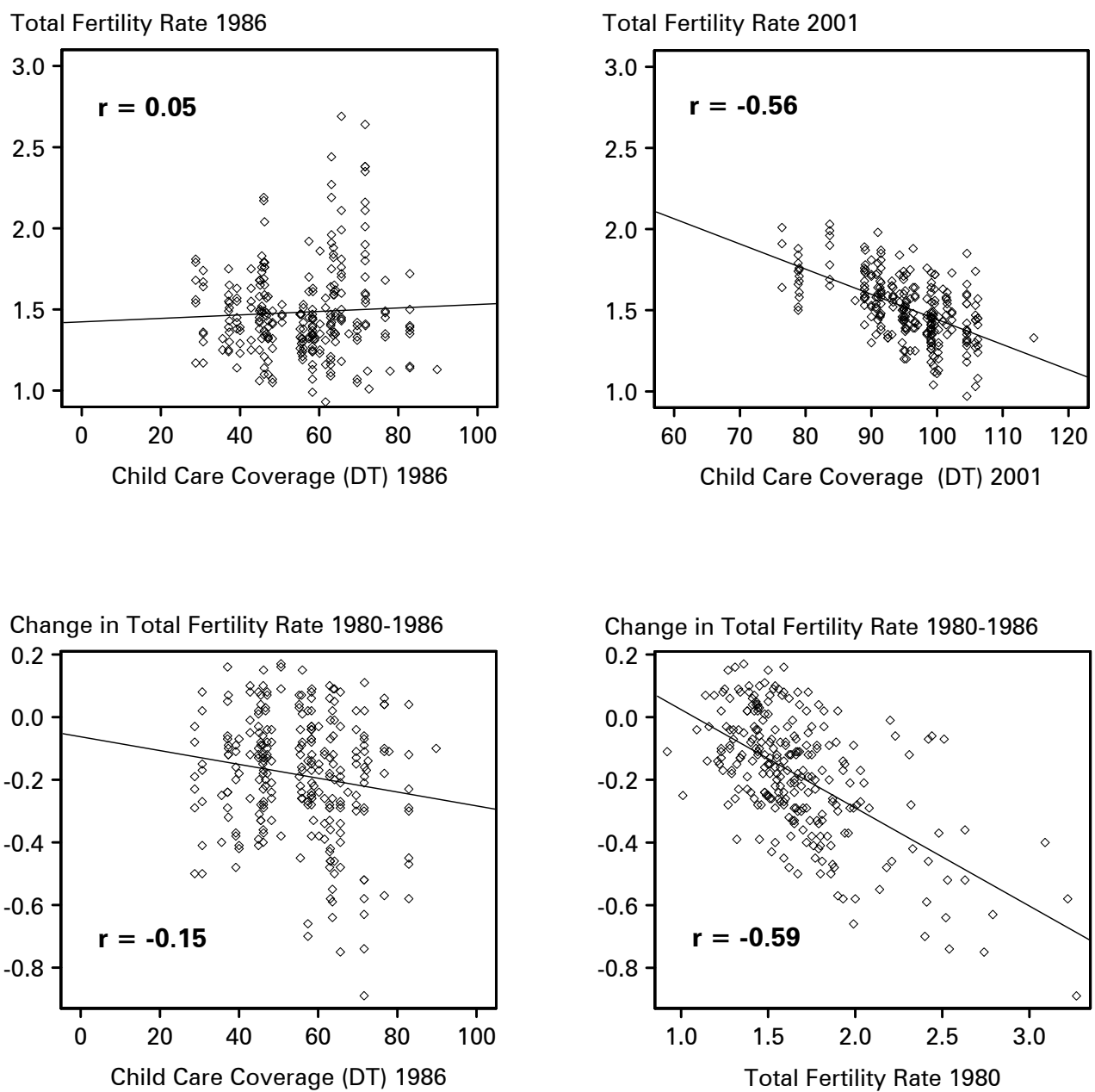

Notes: DT stands for district as these data are only available at the district level.

Source: Statistical Offices of Lower Saxony and Germany, own calculations

and fertility levels (see Fig. 8). The high fertility areas in the western part of Lower Saxony (see Appendix I) appear to be very unusual in terms of the economic development observed over the last 30 years. In the 1970s and early 1980s, this area, which is also called "Emsland", was characterised by very high unemployment levels between $15 \%$ and more than $20 \%$. But this changed rapidly in the 1980 s, also due to large-scale investments (Schrader et al. 2001), turning this area from a rather economically disadvantaged into a very prosperous region. These kinds of economic changes are rarely observed, and it is interesting to investigate whether this trend is associated to fertility levels. 
Fig. 8: $\quad$ TFR and unemployment rate (Lower Saxony)

1986

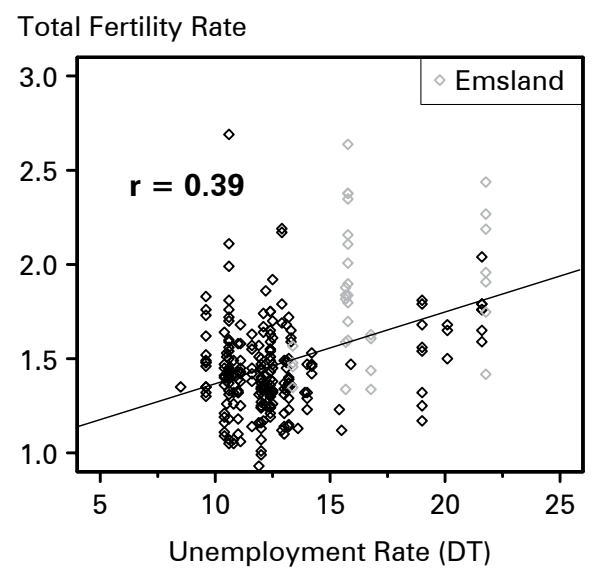

2001

Total Fertility Rate

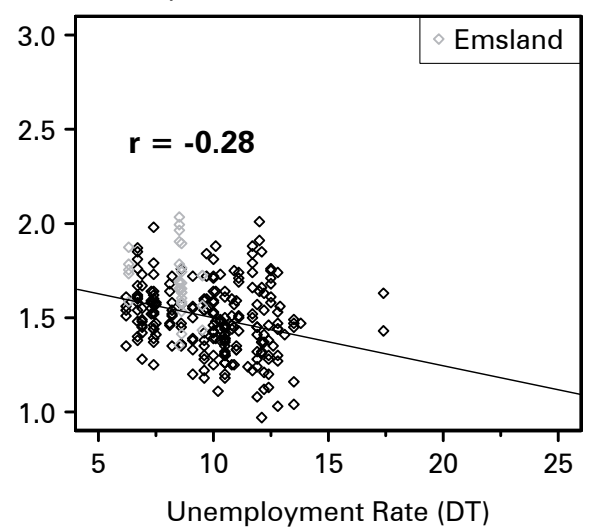

1991

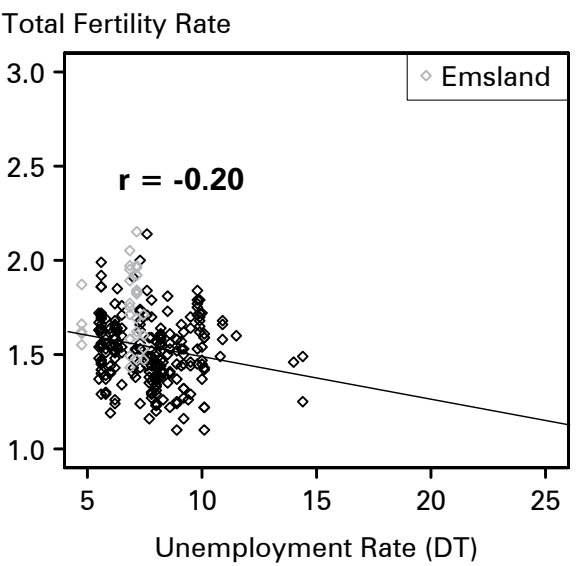

2006

Total Fertility Rate

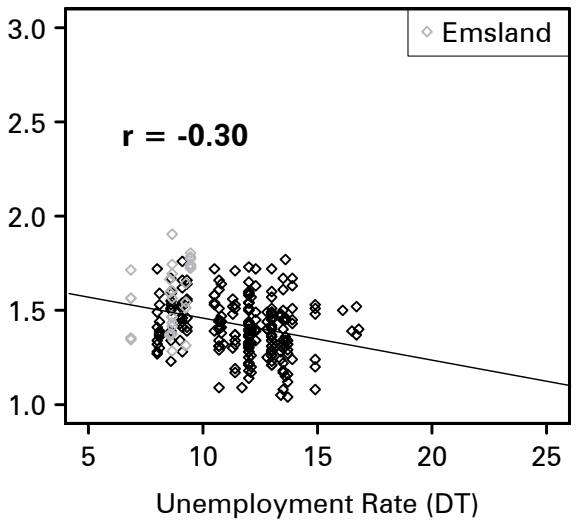

Notes: DT stands for district as these data are only available at the district level.

Source: Statistical Offices of Bremen, Lower Saxony and Germany, own calculations

The figure for 1986 shows that the areas with high fertility rates in the western part of Lower Saxony also had quite high unemployment rates, resulting in a positive ecological association between fertility and unemployment. When these pockets of high unemployment turned into areas with moderate unemployment rates, they continued to have higher fertility levels than the other units in Lower Saxony. As a result, the ecological association between unemployment levels and fertility became negative. The evidence suggests that, in this case, fertility in the western part of Lower Saxony is largely independent of the observed unemployment fig- 
Fig. 9: $\quad$ Path dependency of local TFRs in Lower Saxony and Bremen

Lower Saxony 2006-1971

Total Fertility Rate 2006

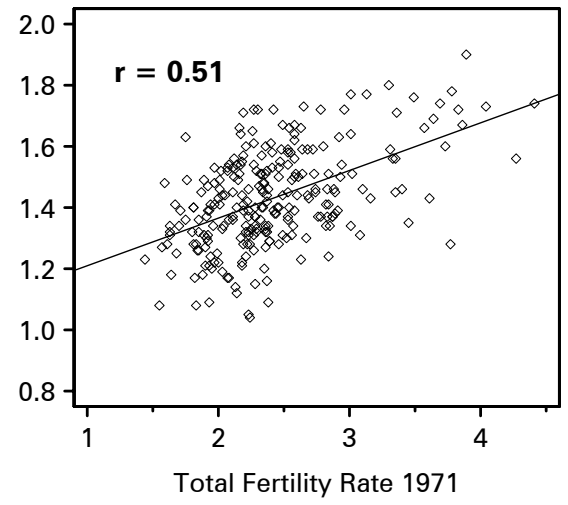

Bremen 2006-1971

Total Fertility Rate 2006

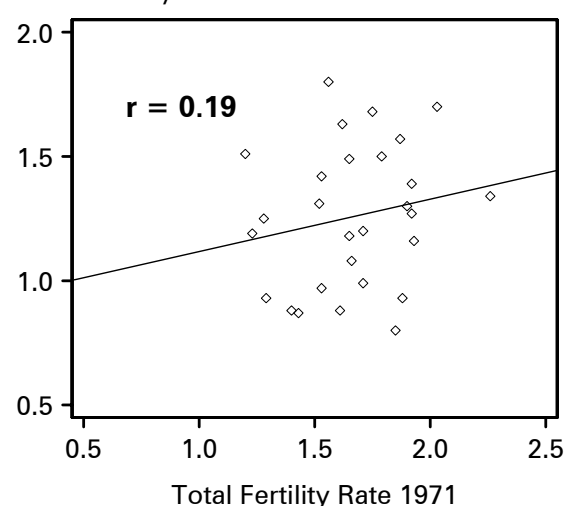

Lower Saxony 2006-1991

Total Fertility Rate 2006

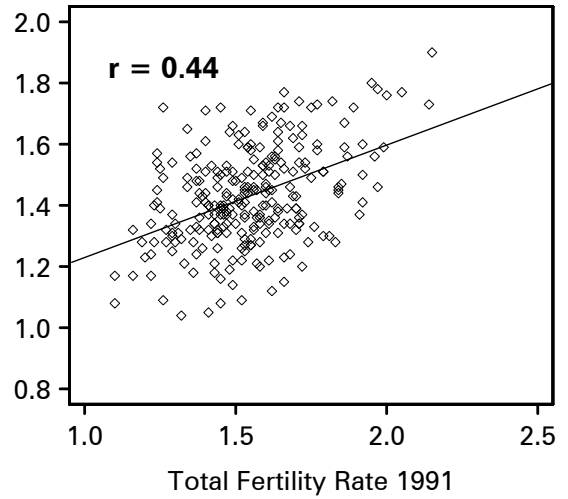

Bremen 2006-1991

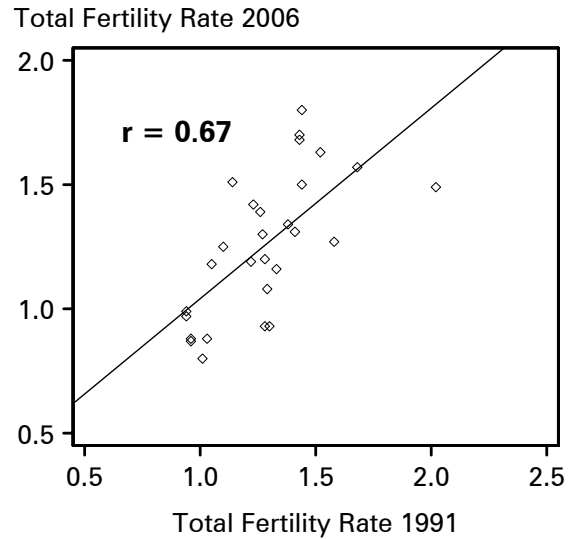

Source: Statistical Offices of Lower Saxony, Bremen and Germany, own calculations

ures. Further study in a multi-level framework that includes individual-level data is needed to provide a better understanding of this interesting change.

In Section 2.5, we noted that children usually grow up in the (local) social and economic setting of their parents, which makes it likely that they will adopt similar norms with regard to fertility decisions. This intergenerational transfer of norms makes cultural inertia very likely, particularly in regions with little in- and out-migration. In those regions, the fertility development should therefore exhibit a strong path dependency. The availability of long-term fertility data allow us to test whether 
there are path dependencies in the spatial fertility variation of Bremen and Lower Saxony. In Figure 9, we present plots for Lower Saxony and Bremen, which contrast the fertility levels of 2006 with those of 1971 and $1991 .{ }^{4}$ In Lower Saxony, we find evidence for a quite substantial path dependency. We even get the surprising result that the values observed in 1971 are slightly stronger associated with the values of 2006 than the values of 1991. With regard to the city districts of Bremen, on the other hand, the levels of 1971 have very little to do with those of 2006. The processes which caused this change in the spatial pattern (expansion of academic institutions, gentrification) have been outlined above. But in 1991, the new spatial fertility regime had already been well established in Bremen, and since then has changed relatively little. The results show that the inner-city processes of polarisation and gentrification can change the fertility regime of localities. It is likely that this is mainly caused by selective migration processes, in which gentrifiers with high socio-economic status move in, while most of the former population with low socio-economic status are forced to leave these gentrified districts in response to rising housing prices.

Generally, our study of Lower Saxony and Bremen shows that fertility convergence at the regional level can coincide with fertility divergence on a smaller geographic scale. Given that many cities in Germany (Friedrichs/Triemer 2009), Austria (Fassmann/Hatz 2006) and Switzerland (Rérat/Lees 2011) have experienced gentrification and segregation trends in recent decades (Krätke 1995), internal patterns of divergence with regard to spatial fertility variation might also be found in other metropolitan areas of these three countries.

The findings also raise doubts about whether the fertility convergence is strongly linked with economic convergence trends, but we would need micro data to study this relationship in an appropriate manner. Based on the evidence, we would suggest that the TFR convergence pattern in Lower Saxony is caused by time lags in the onset of drastic fertility changes. In the case of the fertility decline in the 1960s and 1970s, the population of urban areas experienced the decline earlier than the usual laggards (rural population, Catholics). This does not mean that economic change is not affecting the results, but rather that spatial economic differences and spatial trends of economic divergence and convergence cannot be directly associated with the spatial divergence and convergence trends in fertility development, which are usually observed in such periods. We would, however, need better data and quantitative modelling to study these issues in greater detail.

\section{Discussion and conclusion}

In this paper, we first outlined some of the main theoretical elements which underpin our current knowledge of the social geography of fertility trends. By a multi-faceted empirical analysis of datasets which had not existed in this form so far (a compara-

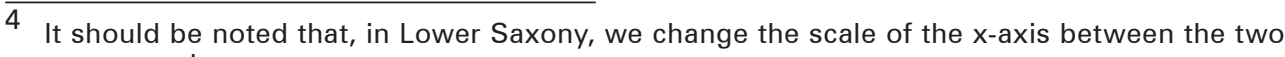
upper graphs. 
tive long-term dataset and two datasets at small geographical scale), we have then tried to show that sub-national spatial fertility variation in Austria, Germany and Switzerland are likely to be shaped by existing cultural, social and economic factors, but that they are also visible in and shaped by new developments.

In a European context, at least, European integration and globalisation have played significant roles in the homogenisation of cultures, economies, societies, languages, currencies and norms; and the freedom and capacity to travel, work and live within Europe has opened up new opportunities to migrate. As sub-national regions sometimes struggle to define and maintain their historical identity and integrity in the face of these challenges, both within their countries and within Europe as a whole, it is hardly surprising that NUTS-1 and -2 (and even NUTS-3) level fertility should reflect this kind of convergence.

By juxtaposing a historical outlook with a very focused small-scale case study, we suggest however, that over the past few decades, development processes within cities have fostered a degree of inner-city divergence which is, in turn, likely to continue in the future.

As such, "divergence within convergence", despite a contradiction in terms, does seem to characterise the recent trends and likely future trajectories in sub-national fertility best. This is also supported by the observation that family formation and fertility behaviour has diversified at the individual level over recent decades (e.g. Brückner/Mayer 2005).

In this setting, the question of regional differences in fertility is therefore still on the agenda despite the macro-regional convergence. From studying the differences between and within German-speaking countries, we can see that dealing with regional disparities in fertility forces us to think about better theoretical models to improve our understanding of the complex interplay of different dimensions of the life course in societal contexts.

By using datasets with increasingly fine-graded geographic scale, we are able to gain a deeper understanding of the relationship between regional and local conditions and fertility decisions of humans. As discussed earlier, these include the material and institutional (infra-)structure, economic and socio-structural factors, cultural factors and the embeddedness in social contexts. The local conditions of organising a life course are considered as part of the opportunity structure of welfare production. Individuals are to a certain degree able to modify those conditions or to elude from them by moving to another region.

Finally, exploring the complex interrelationship between regional conditions, the fertility behaviour of the population and migration processes would require the framework of a longitudinal perspective of analysis. Ideally, these studies should be based on a combination of individual-level data and contextual data; for example, in Austria, such research could utilise future waves of the Generations and Gender Survey (GGS), while research on Germany could be based on future waves of the PAIRFAM study. 


\section{Acknowledgement}

This publication was generated in the context of the interdisciplinary working group Future with Children - Fertility and the Development of Society. This group has been jointly established by the Berlin-Brandenburgische Akademie der Wissenschaften and the Nationale Akademie der Wissenschaften Leopoldina and is funded by the Jacobs Foundation.

\section{References}

Adriaanse, Carlinde 2007: Measuring Residential Satisfaction: A Residential Environmental Satisfaction Scale (RESS). In: Journal of Housing and the Built Environment 22,3: 287-304 [doi: 10.1007/s10901-007-9082-9].

Agnew, John 2008: Borders on the Mind: Re-framing Border Thinking. In: Ethics and Global Politics 1,4: 175-191.

Anderson, Barbara 1986: Regional and Cultural Factors in the Decline of Marital Fertility in Western Europe. In: Coale, Ansley J.; Watkins, Susan C. (Eds.): The Decline of Fertility in Europe. Princeton, NJ: Princeton University Press: 293-314.

Andersson, Gunnar 2000: The Impact of Labour-force Participation on Childbearing Behaviour: Pro-cyclical Fertility in Sweden During the 1980s and the 1990s. In: European Journal of Population/Revue européenne de Démographie 16,4: 293-333 [doi: 10.1023/A:1006454909642].

Armingeon, Klaus; Bertozzi, Fabio; Bonoli, Giuliano 2004: Swiss Worlds of Welfare. In: West European Politics 27: 20-44 [doi: 10.1080/01402380412331280793].

Baizán, Pau 2009: Regional Child Care Availability and Fertility Decisions in Spain. In: Demographic Research 21,27: 803-842 [doi: 10.4054/DemRes.2009.21.27].

Basten, Stuart A. 2010: Television and Fertility. In: Finnish Yearbook of Population Research XLV: 67-82.

Becker, Gary S. 1991: A Treatise on the Family. Cambridge, MA: Harvard University Press.

Blau, Peter M. 1977: Inequality and Heterogeneity: A Primitive Theory of Social Structure. New York, NY: Free Press.

Blossfeld, Hans-Peter; Huinink, Johannes 1991: Human Capital Investments or Norms of Role Transition? How Women's Schooling and Career Affect the Process of Family Formation. In: The American Journal of Sociology 97,1: 143-168.

Bonoli, Giuliano 2008: The Impact of Social Policy on Fertility: Evidence from Switzerland. In: Journal of European Social Policy 18,1: 64-77 [doi: 10.1177/0958928707081074].

Boyle, Paul 2003: Population Geography: Does Geography Matter in Fertility Research? In: Progress in Human Geography 27: 615-626 [doi: 10.1191/0309132503ph452pr].

Brown, John; Guinnane, Timothy 2007: Regions and Time in the European Fertility Transition: Problems in the Princeton Project's Statistical Methodology. In: The Economic History Review 60,3: 574-595 [doi: 10.1111/j.1468-0289.2006.00371.x].

Brückner, Hannah; Mayer, Karl Ulrich 2005: De-standardization of the Life-course: What it Might Mean? And if it Means Anything, Whether it Actually Took Place. In: Macmillan, Ross (Eds.): The Structure of the Life Course: Standardized? Individualized? Differentiated)? Amsterdam: Elsevier: 27-53. 
Buettner, Thomas; Lutz, Wolfgang 1990: Estimating Fertility Responses to Policy Measures in the German Democratic Republic. In: Population and Development Review 16,3: 539-555.

Cairncross, Frances 2001: The Death of Distance: How the Communications Revolution is Changing our Lives. Boston, MA: Harvard Business School Press.

Carstairs, Vera 1981: Small Area Analysis and Health Service Research. In: Journal of Public Health 3,2: 131-139.

Coale, Ansley J.; Treadway, Roy 1986: A Summary of the Changing Distribution of Overall Fertility, Marital Fertility, and the Proportion Married in the Provinces of Europe. In: Coale Ansley J.; Watkins, Susan C. (Eds.): The Decline of Fertility in Europe. The Revised Proceedings of a Conference on the Princeton European Fertility Project. Princeton, NJ: Princeton University Press: 31-181.

Coale, Ansley J.; Watkins, Susan C. (Eds.) 1986: The Decline of Fertility in Europe: The Revised Proceedings of a Conference on the Princeton European Fertility Project. Princeton, N.J.: Princeton University Press.

Coleman, David 1993: Britain in Europe: International and Regional Comparisons of Fertility Levels and Trends. In: Ni Bhrolchain, Maire (Eds.): New Perspectives on Fertility in Britain. London: HMSO: 67-92.

Cuadrado-Roura, Juan R. 2001: Regional Convergence in the European Union: From Hypothesis to the Actual Trends. In: The Annals of Regional Science 35,3: 333-356.

Demeny, Paul 1968: Early Fertility Decline in Austria-Hungary: A Lesson in Demographic Transition. In: Daedalus 97,2: 502-522.

Eurostat 2010a: Regional Yearbook. Luxembourg: Eurostat.

Eurostat 2010b: NUTS - Nomenclature of Territorial Units for Statistics: Introduction. In: ec.europa.eu/eurostat, 2010. [http://epp.eurostat.ec.europa.eu/portal/page/portal/ nuts nomenclature/introduction, 5.1.2011].

Fassmann, Heinz; Hatz, Gerhard 2006: Urban Renewal in Vienna. In: Enyedi, György; Kovács, Zoltán (Eds.): Social Change and Social Sustainability in Historical Urban Centres: The Case of Central Europe. Pecs: Centre for Regional Studies of Hungarian Academy of Sciences: 218-236.

Federal Agency for Cartography and Geodesy in Germany 2007: VG 250 - Verwaltungsgebiete (Ebenen) $1: 250000$. Frankfurt am Main: Federal Agency for Cartography and Geodesy in Germany.

Friedrichs, Jürgen; Triemer, Sascha 2009: Gespaltene Städte? Soziale und ethnische Segregation in deutschen Großstädten. Wiesbaden: VS-Verlag.

GAFP 2010: GAFP: The First Demographic Transition in Austria 1869-1937. In: uni-graz.at 2010. [http://www.uni-graz.at/en/wsgwww/wsgwww-gafp/wsgwww-gafp_home-2. htm. 1.11.2010].

Galloway, Patrick et al. 1994: Fertility Decline in Prussia, 1875-1910: A Pooled Crosssection Time Series Analysis. In: Population Studies 48,1: 135-158.

Giddens, Anthony 1990: The Consequences of Modernity. Cambridge, UK: Polity Press.

Gisser, Richard 1975: Die persönliche Situation der Frau. Vienna: Bundeskanzleramt.

Goldstein, Joshua R.; Kreyenfeld, Michaela 2011: Has East Germany Overtaken West Germany?: Recent Trends in Order-specific Fertility. In: Population and Development Review 37,3: 453-472 [doi:10.1111/j.1728-4457.2011.00430.x]. 
Graham, Stephan 1998: The End of Geography or the Explosion of Place? Conceptualizing Space, Place and Information Technology. In: Progress in Human Geography 22,2: 165-185.

Gude, Stefanie 2010: Regionale Fertilitätsunterschiede in Österreich. Eine Mehrebenenanalyse zu den Einflüssen auf das generative Verhalten unter Berücksichtigung von räumlichen Abhängigkeiten. PhD. Diss. Thesis. Vienna: Vienna University of Economics and Business.

Haandrikman, Karen; Harmsen, Carel N.; Van Wissen, Leo J.G.; Hutter, Inge 2008: Geography Matters: Patterns of Spatial Homogamy in the Netherlands. In: Population, Space and Place 14,5: 387-405 [doi: 10.1002/psp.487].

Haandrikman, Karen; van Wissen, Leo; Harmsen, Carel N. 2010: Explaining Spatial Homogamy. Compositional, Spatial and Regional Cultural Determinants of Regional Patterns of Spatial Homogamy in the Netherlands. In: Applied Spatial Analysis and Policy 3: 1-19 [doi: 10.1007/s12061-009-9044-6].

Hajnal, John 1965: European Marriage Pattern in Historical Perspective. In: Glass, David V.; Eversley, David E.C. (Eds.): Population in History. London: 101-143.

Hank, Karsten 2002: Regional Social Contexts and Individual Fertility Decisions: A Multilevel Analysis of First and Second Births in Western Germany. In: European Journal of Population/Revue européenne de Démographie 18,3: 281-299. [doi: 10.1023/A:1019765026537].

Harvey, David 1990: The Condition of Postmodernity: An Enquire into the Origins of Cultural Change. Oxford: Oxford University Press.

Huinink, Johannes 2002: Polarisierung der Familienentwicklung in europäischen Ländern im Vergleich. In: Schneider, Norbert F.; Matthias-Bleck, Heike (Eds.): Elternschaft heute. Gesellschaftliche Rahmenbedingungen und individuelle Gestaltungsaufgaben. Zeitschrift für Familienforschung, Special Issue 2. Opladen: 49-74.

Huinink, Johannes; Wagner, Michael 1989: Regionale Lebensbedingungen, Migration und Familienbildung. In: Kölner Zeitschrift für Soziologie und Sozialpsychologie 41,4: 669-689.

Inglehart, Ron 1977: The Silent Revolution: Changing Values and Political Styles Among Western Publics. Princeton, NJ: Princeton University Press.

Jaich, Roman 2003: Finanzierung der Kindertagesbetreuung in Deutschland: Gutachten im Rahmen des Projektes „Familien unterstützende Kinderbetreungsangebote des DJI. Munich.

Keim, Sylvia; Klärner, Andreas; Bernardi, Laura 2009: Fertility-relevant Social Networks: Composition, Structure, and Meaning of Personal Relationships for Fertility Intentions. In: Current Sociology 57,6: 1-20.

Klüsener, Sebastian 2009: An Alternative Framework for Studying the Effects of Family Policies on Fertility in the Absence of Individual-level Data: A Spatial Analysis with Small-scale Macro-data on Germany. MPIDR Working Paper. Rostock: MPIDR. 2009-027.

Klüsener, Sebastian; Kreyenfeld, Michaela 2009: Nichteheliche Geburten im regionalen Vergleich. In: nationalatlas aktuell. Leipzig: Leibniz-Instituts für Länderkunde.

Klüsener, Sebastian; Goldstein, Joshua R. 2012: Der Einsatz räumlicher GIS-basierterModelle in der Historischen Demografie. In: Busch, Michael; Kroll, Stefan; Scholz, Rembrand (Eds.): Geschichte - Kartographie - Demographie. Historisch-geographische Informationssysteme im methodischen Vergleich. Münster: LIT Verlag. 
Knodel, John E. 1974: The Decline of Fertility in Germany, 1871-1939. Princeton, N.J.: Princeton University Press.

Kohler, Hans-Peter 2001: Fertility and Social Interaction: An Economic Perspective. New York: Oxford University Press.

Krätke, Stefan 1995: Stadt, Raum, Ökonomie: Einführung in aktuelle Problemfelder der Stadtökonomie und Wirtschaftsgeographie. Basel.

Kravdal, Østein 1996: How the Local Supply of Day-care Centers Influences Fertility in Norway: A Parity-specific Approach. In: Population Research and Policy Review 15,3: 201-218.

Kreyenfeld, Michaela; Mika, Tatjana 2008: Erwerbstätigkeit und Fertilität: Analysen mit der Versicherungskontenstichprobe der deutschen Rentenversicherung. In: Workshop des Forschungsdatenzentrums der Rentenversicherung FDZ-RV: Deutsche Rentenversicherung Bund. Würzburg: 71-95.

Kreyenfeld, Michaela; Zeman, Kryštof; Burkimsher, Marion; Jaschinski, Ina 2011: Fertility Data for German-speaking Countries. What is the Potential? Where are the Pitfalls? In: Comparative Population Studies - Zeitschrift für Bevölkerungswissenschaft 36,2-3 [doi: 10.4232/10.CPoS-2011-06en].

Kulu, Hill 2005: Migration and Fertility: Competing Hypotheses Re-examined. In: European Journal of Population/Revue européenne de Démographie 21,1: 51-87 [doi: 10.1007/s10680-005-3581-8].

Kulu, Hill; Boyle, Paul J. 2009: High Fertility in City Suburbs: Compositional or Contextual Effects? In: European Journal of Population/Revue européenne de Démographie 25,2: 157-174. [doi: 10.1007/s10680-008-9163-9].

Kulu, Hill; Milewski, Nadja 2007: Family Change and Migration in the Life Course: An Introduction. In: Demographic Research 17,19: 567-590. [doi: 10.4054/ DemRes.2007.17.19]:

Kulu, Hill; Vikat, Andres 2008: Fertility Differences by Housing Type: An Effect of Housing Conditions or of Selective Moves? In: Demographic Research, 17,26: 775-802 [doi: 10.4054/DemRes.2007.17.26].

Lesthaeghe, Ron 1980: On the Social Control of Human Reproduction. In: Population and Development Review 6,4: 527-548.

Lesthaeghe, Ron; Neels, Kare/ 2002: From the First to the Second Demographic Transition: An Interpretation of the Spatial Continuity of Demographic Innovation in France, Belgium and Switzerland. [De la première à la deuxième transition démographique: Une interpretation de la continuité spatiale de l'innovation démographique en France, Belgique et Suisse] In: European Journal of Population/Revue européenne de Démographie 18,4: 325-360.

Lesthaeghe, Ron; Neidert, Lisa 2006: The Second Demographic Transition in the United States: Exception or Textbook Example? In: Population and Development Review 32,4: 669-698 [doi: 10.1111/j.1728-4457.2006.00146.x].

Lesthaeghe, Ron; Wilson, Chris 1986: Modes of Production, Secularization, and the Pace of the Fertility Decline in Western Europe, 1870-1930. In: Coale, Ansley J.; Watkins, Susan C. (Eds.): The Decline of Fertility in Europe. The Revised Proceedings of a Conference on the Princeton European Fertility Project. Princeton, NJ: Princeton University Press: $260-293$.

Lichter, Daniel; LeClere, Felicia; McLaughlin, Diane K. 1991: Local Marriage Markets and the Marital Behavior of Black and White Women. In: American Journal of Sociology 96,4: 843-867. 
Lloyd, Kim M.; South, Scott J. 1996: Contextual Influences on Young Men's Transition to First Marriage. In: Social Forces 74,3: 1097-1119.

Lutz, Wolfgang; Hanika, Alexander 1989: Vienna: A City Beyond Aging. In: Bulletin of the American Academy of Arts and Sciences 42,4: 14-21.

Maloutas, Thomas 2004: Editorial: Urban Segregation and the European Context. In: The Greek Review of Social Research 113: 3-24.

Menzel, Ulrich 1998: Globalisierung versus Fragmentierung. Frankfurt am Main: Suhrkamp.

Montgomery, Mark; Casterline, John 1996: Social Learning, Social Influence, and New Models of Fertility. In: Population and Development Review 22, supplement: 151-175.

MPIDR and VID 2010: Human Fertility Database. In: Human Fertility Database 12.11.2010. URL: www.humanfertility.org, 2.2.2011.

Mulder, Clara 2006a: Home-ownership and Family Formation. In: Journal of Housing and the Built Environment 21,3: 281-298 [doi: 10.1007/s10901-006-9050-9].

Mulder, Clara 2006b: Population and Housing: A Two-sided Relationship. In: Demographic Research 15,13: 401-412.

Mulder, Clara; Wagner, Michael 2001: The Connections Between Family Formation and First-time Home Ownership in the Context of West Germany and the Netherlands. In: European Journal of Population/Revue européenne de Démographie 17,2: 137-164 [doi: 10.1023/A:1010706308868].

Nauck, Bernhard 1995: Regionale Milieus von Familien in Deutschland nach der politischen Vereinigung. In: Nauck, Bernhard; Onnen-Isemann, Corinna (Eds.): Familie im Brennpunkt von Wissenschaft und Forschung. Neuwied: Luchterhand: 91-121.

Neyer, Gerda; Andersson, Gunnar 2008: Consequences of Family Policies on Childbearing Behavior: Effects or Artifacts? In: Population and Development Review 34,4: 699-724 [doi: 10.1111/j.1728-4457.2008.00246.x].

Pine, Lisa 1997: Nazi Family Policy, 1933-1945. Oxford \& New York: Berg.

Rérat, Patrick; Lees, Loretta 2011: Spatial Capital, Gentrification and Mobility: Evidence from Swiss Core Cities. In: Transactions of the Institute of British Geographers 36,1: 126-142 [doi: 10.1111/j.1475-5661.2010.00404.x].

Rossier, Clémentine; Bernardi, Laura 2009: Social Interaction Effects on Fertility: Intentions and Behaviors. In: European Journal of Population/Revue européenne de Démographie 25,4: 467-485 [doi: 10.1007/s10680-009-9203-0].

Sardon, Jean-Paul 1996: Coale's Indices, Comparative Indices, Mean Generation, Total Fertility Rate and Components. In: Population: An English Selection 8: 252-257.

Sassen, Saskia 1991: The Global City: New York, London, Tokyo. Princeton: NJ: Princeton University Press.

Schrader, Helmut; Hachmöller, Gerd; Koch, Birgit; Masurek, Lars 2001: Dynamic of Rural Areas (DORA): National Report, Germany. Braunschweig.

Sharlin, Allan 1986: Urban-Rural Differences in Fertility in Europe during the Demographic Transition. In: Coale, Ansley J.; Watkins, Susan C. (Eds.): The Decline of Fertility in Europe. Princeton, NJ: Princeton University Press: 234-261.

Snyder, Richard 2001: Scaling Down: The Subnational Comparative Method. In: Studies in Comparative International Development (SCID) 36,1: 93-110. 
Sobotka, Tomaš 2002: Comments on The Empirical Analysis of East German Fertility after Unification: An Update. In: European Journal of Population/Revue européenne de Démographie 18,3: 203-208.

Sobotka, Tomaš; Lutz, Wolfgang 2009: Misleading Policy Messages from the TFR. Should we Stop Using it? European Demographic Research Papers. Vienna: Vienna Institute of Demography

Statistisches Landesamt Baden-Württemberg 2007: Der demografische Wandel in Baden-Württemberg. Stuttgart.

Strohmeier, Klaus P.; Kersting, Volker 1996: Sozialraum Ruhrgebiet - Stadträumliche Differenzierungen von Lebenslagen, Armut und informelle Solidarpotentiale. In: Das Ruhrgebiet - ein starkes Stück Nordrhein-Westfalen. Essen: Klartext: 451-475.

Szreter, Simon 1996: Fertility, Class, and Gender in Britain, 1860-1940. Cambridge/New York: Cambridge University Press.

Vatter, Adrian 2002: Kantonale Demokratien im Vergleich: Entstehungsgründe, Interaktionen und Wirkungen politischer Institutionen in den Schweizer Kantonen. Opladen: Leske \& Budrich.

Veltz, Pierre 1996: Mondialisation, villes et territoires. Paris: Presse Universitaires de France

Wanner, Philippe 2002: The Demographic Characteristics of Immigrant Populations in Switzerland. In: Haug, Werner; Compton, Paul; Courbage, Youssef (Eds.): The Demographic Characteristics of Immigrant Populations. Strasbourg: Council of Europe Publishing.

Wanner, Philippe; Fei, Peng 2004: La fécondité en Suisse. Facteurs influençant le comportement reproductif des Suissesses et des Suisses. Neuchâtel: Office fédéral de la statistique.

Watkins, Susan C. 1991: From Provinces into Nations: Demographic Integration in Western Europe, 1870-1960. Princeton, NJ: Princeton University Press.

Werlen, Benno 1995: Sozialgeographie alltäglicher Regionalisierungen. Band 1: Zur Ontologie von Gesellschaft und Raum. Stuttgart: Steiner.

Zeman, Kryštof 2010: Geburtenbarometer Vienna: An Overview Report. Vienna, Austria. 
A German translation of this reviewed and author's authorised original article by the authors is available under the title "Räumliche Unterschiede in der subnationalen Fertilitätsentwicklung in Österreich, Deutschland und der Schweiz", DOI 10.4232/10.CPoS-2011-08de or URN urn:nbn:de:bibcpos-2011-08de5, at http://www.comparativepopulationstudies.de.

Date of submission: 07.02.2011

Date of Acceptance: 19.05 .2011

Dr. Stuart Basten ( $₫)$. Department of Social Policy and Intervention, University of Oxford, 32 Wellington Square, Oxford OX1 2ER, United Kingdom.

E-Mail: stuart.basten@spi.ox.ac.uk

URL: www.spi.ox.ac.uk

Prof. Dr. Johannes Huinink. Universität Bremen, Institut für angewandte und empirische Soziologie (EMPAS), 28359 Bremen, Germany. E-Mail: huinink@empas.uni-bremen.de URL: http://www.soziologie.uni-bremen.de

Dr. Sebastian Klüsener. Max Planck Institute for Demographic Research, 18057 Rostock, Germany. E-Mail: kluesener@demogr.mpg.de

URL: http://www.demogr.mpg.de

In alphabetical order. 
Appendix I: The Spatio-temporal Emergence of Sub-replacement Period TFRs in Lower Saxony and Bremen

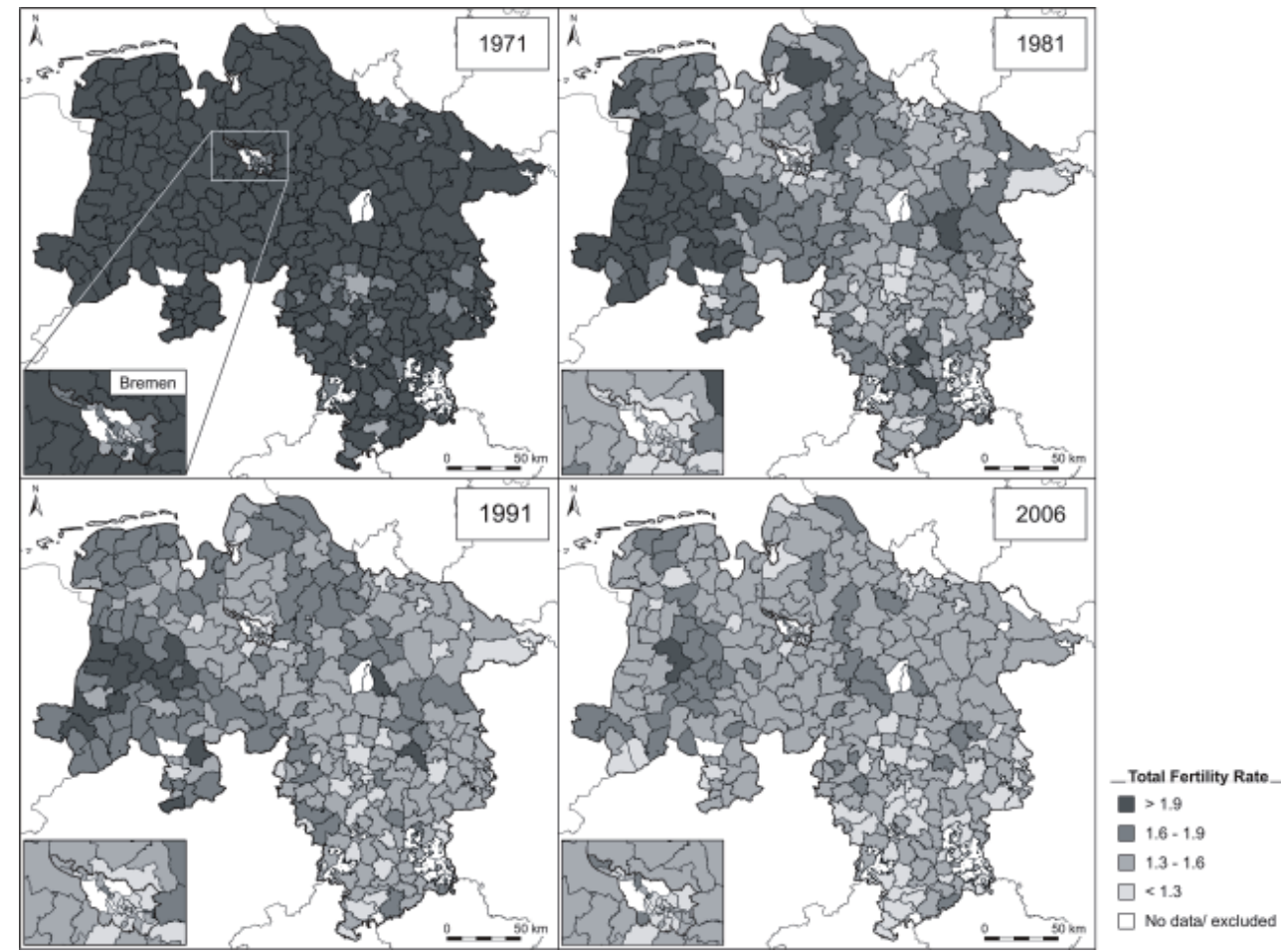

Source: Statistical Offices of Bremen and Lower Saxony, own calculations; Base Map: Federal Agency for Cartography and Geodesy in Germany (2007), modified 
Appendix II: Estimated TFR for German PEFT Provinces 1867-1933, ordered at 1933 (excluding territories East of Oder-Neiße-border)

\begin{tabular}{|c|c|c|c|c|c|c|c|c|c|c|c|c|c|}
\hline PEFT Province & $\begin{array}{l}\text { Indicative } \\
\text { NUTS-1 } \\
\text { Region }\end{array}$ & 1867 & 1871 & 1875 & 1880 & 1885 & 1890 & 1895 & 1900 & 1905 & 1910 & 1925 & 1933 \\
\hline Berlin & $\mathrm{BE}$ & 4.08 & 3.91 & 4.42 & 3.98 & 3.52 & 3.21 & 2.96 & 2.70 & 2.54 & 2.28 & 1.06 & 1.12 \\
\hline Hamburg & $\mathrm{HH}$ & 3.63 & 3.92 & 4.34 & 4.23 & 4.01 & 3.99 & 3.89 & 3.36 & 2.96 & 2.61 & 1.47 & 1.42 \\
\hline Dresden & $\mathrm{SN}$ & 4.50 & 4.59 & & 4.79 & 4.69 & 4.55 & & 4.34 & & 3.07 & 1.80 & 1.48 \\
\hline Leipzig & SN & 4.90 & 5.01 & & 5.26 & 5.21 & 5.05 & & 4.39 & & 3.18 & 1.79 & 1.48 \\
\hline Zwickau & $\mathrm{SN}$ & 5.91 & 6.00 & & 6.03 & 6.05 & 5.81 & & 5.16 & & 3.68 & 1.97 & 1.48 \\
\hline Wiesbaden & $\mathrm{HE}$ & 4.23 & 4.27 & & 4.09 & 3.82 & 3.63 & 3.61 & 3.60 & 3.41 & 2.95 & 1.85 & 1.53 \\
\hline Bremen & $\mathrm{HB}$ & 3.97 & 4.15 & 4.55 & 4.23 & 3.79 & 3.61 & 3.55 & 3.52 & 3.47 & 3.00 & 1.79 & 1.60 \\
\hline Hannover & $\mathrm{NI}$ & 4.47 & 4.43 & & 4.48 & 4.38 & 4.25 & 4.24 & 4.07 & 3.58 & 3.09 & 1.78 & 1.60 \\
\hline Lübeck & $\mathrm{SH}$ & 3.82 & 3.92 & 4.29 & 4.23 & 4.13 & 4.03 & & 3.84 & 3.64 & 3.13 & 1.92 & 1.63 \\
\hline Köln & NW & 4.58 & 4.73 & & 4.99 & 4.85 & 4.85 & 4.67 & 4.65 & 4.35 & 3.71 & 2.15 & 1.68 \\
\hline Neckarkreis & BW & & 5.22 & 5.81 & 5.29 & 4.78 & 4.42 & & 4.23 & & 3.55 & 1.94 & 1.72 \\
\hline Schaumburg-Lippe & NW & & 4.49 & & 4.44 & 4.40 & 4.08 & & 3.99 & & 3.36 & 2.00 & 1.73 \\
\hline Düsseldorf & NW & 5.05 & 5.22 & & 5.35 & 5.22 & 5.06 & 4.96 & 4.98 & 4.74 & 4.04 & 2.11 & 1.74 \\
\hline Braunschweig & $\mathrm{NI}$ & & 4.48 & 4.91 & 4.63 & 4.59 & 4.55 & 4.43 & 4.23 & 3.74 & 3.27 & 2.10 & 1.77 \\
\hline Mittelfranken & BY & 4.79 & 4.99 & 5.44 & 5.08 & 4.85 & 4.62 & & 4.50 & & 3.63 & 2.08 & 1.79 \\
\hline Oberbayern & BY & 5.05 & 5.20 & 5.73 & 5.40 & 5.09 & 4.83 & & 4.58 & & 3.63 & 2.11 & 1.79 \\
\hline Rheinhessen & $\mathrm{RP}$ & & 4.57 & & 4.55 & 4.29 & 4.09 & 3.92 & 3.98 & 3.76 & 3.28 & 2.18 & 1.82 \\
\hline Starkenburg & $\mathrm{HE}$ & & 5.08 & & 4.88 & 4.54 & 4.39 & 4.40 & 4.54 & 4.37 & 3.81 & 2.25 & 1.84 \\
\hline Arnsberg & NW & 5.54 & 5.86 & & 6.06 & 6.00 & 5.93 & 5.90 & 5.93 & 5.73 & 5.03 & 2.55 & 1.87 \\
\hline Magdeburg & ST & 4.78 & 4.76 & & 4.98 & 5.03 & 4.85 & 4.67 & 4.37 & 3.86 & 3.52 & 2.19 & 1.88 \\
\hline Thüringen & $\mathrm{TH}$ & & 4.73 & 5.13 & 4.85 & 4.88 & 4.78 & & 4.65 & & 3.82 & 2.40 & 1.88 \\
\hline Mannheim & BW & & 5.14 & & 5.15 & 4.93 & 4.79 & & 4.83 & & 4.11 & 2.44 & 1.90 \\
\hline Karlsruhe & BW & & 5.25 & & 5.04 & 4.69 & 4.43 & & 4.49 & & 3.83 & 2.38 & 1.92 \\
\hline Erfurt & TH & 4.93 & 5.10 & & 5.10 & 5.00 & 4.81 & 4.59 & 4.43 & 4.13 & 3.71 & 2.33 & 1.93 \\
\hline Potsdam & BB & 4.73 & 4.71 & & 4.98 & 4.85 & 4.73 & 4.35 & 3.76 & 3.20 & 2.60 & 2.03 & 1.94 \\
\hline Anhalt & ST & & 4.76 & 5.16 & 5.00 & 5.04 & 4.95 & & 4.47 & & 3.42 & 2.39 & 2.00 \\
\hline Lippe & NW & & 4.73 & & 4.94 & 4.89 & 4.89 & & 4.65 & & 4.09 & 2.46 & 2.00 \\
\hline Minden & NW & 4.78 & 4.80 & & 4.99 & 4.94 & 4.84 & 4.80 & 4.71 & 4.43 & 3.97 & 2.46 & 2.00 \\
\hline Oberhessen & $\mathrm{HE}$ & & 4.43 & & 4.30 & 4.06 & 3.86 & 3.86 & 3.82 & 3.69 & 3.42 & 2.45 & 2.02 \\
\hline Frankfurt/ Oder & BB & 4.76 & 4.85 & & 4.95 & 4.90 & 4.86 & 4.65 & 4.45 & 4.07 & 3.63 & 2.34 & 2.03 \\
\hline Hildesheim & $\mathrm{NI}$ & 4.50 & 4.53 & & 4.65 & 4.57 & 4.55 & 4.49 & 4.37 & 4.01 & 3.63 & 2.36 & 2.03 \\
\hline Kassel & $\mathrm{HE}$ & 4.52 & 4.65 & & 4.74 & 4.49 & 4.43 & 4.28 & 4.22 & 4.06 & 3.66 & 2.45 & 2.04 \\
\hline Schleswig & $\mathrm{SH}$ & 4.40 & 4.33 & & 4.65 & 4.63 & 4.63 & 4.64 & 4.43 & 4.18 & 3.79 & 2.16 & 2.05 \\
\hline Schwaben & BY & 4.96 & 5.27 & 5.83 & 5.65 & 5.32 & 5.00 & & 4.75 & & 4.22 & 2.49 & 2.05 \\
\hline Lüneburg & $\mathrm{NI}$ & 3.97 & 3.97 & & 4.09 & 4.13 & 4.11 & 4.22 & 4.15 & 3.93 & 3.69 & 2.30 & 2.08 \\
\hline Schwarzwaldkreis & BW & & 5.65 & 6.01 & 5.57 & 5.16 & 4.90 & & 4.86 & & 4.35 & 2.40 & 2.08 \\
\hline Merseburg & ST & 5.19 & 5.24 & & 5.59 & 5.67 & 5.57 & 5.30 & 5.10 & 4.62 & 4.17 & 2.64 & 2.09 \\
\hline Donaukreis & BW & & 5.49 & 5.97 & 5.66 & 5.25 & 4.81 & & 4.74 & & 4.25 & 2.49 & 2.10 \\
\hline Fürstentum Lübeck & $\mathrm{SH}$ & 4.57 & 4.54 & 4.85 & 4.79 & 5.03 & 4.91 & 4.85 & 4.79 & 4.67 & 4.35 & 2.46 & 2.13 \\
\hline Pfalz & $\mathrm{RP}$ & 4.65 & 5.09 & 5.65 & 5.27 & 5.05 & 4.83 & & 4.91 & & 4.29 & 2.61 & 2.13 \\
\hline Aachen & $\mathrm{RP}$ & 4.64 & 4.80 & & 4.91 & 4.83 & 4.84 & 4.79 & 4.74 & 4.50 & 4.12 & 2.67 & 2.14 \\
\hline Birkenfeld & RP & 4.54 & 4.68 & 5.03 & 4.84 & 4.80 & 4.76 & 4.67 & 4.79 & 4.69 & 4.38 & 2.87 & 2.15 \\
\hline Koblenz & $\mathrm{RP}$ & 4.49 & 4.63 & & 4.81 & 4.63 & 4.55 & 4.52 & 4.48 & 4.29 & 3.91 & 2.65 & 2.15 \\
\hline Freiburg & BW & & 4.37 & & 4.33 & 4.08 & 3.92 & & 3.96 & & 3.56 & 2.48 & 2.16 \\
\hline Konstanz & BW & & 4.94 & & 4.91 & 4.50 & 4.27 & & 4.22 & & 3.86 & 2.59 & 2.20 \\
\hline Sigmaringen & BW & 4.80 & 5.11 & & 5.25 & 4.73 & 4.38 & 4.32 & 4.48 & 4.42 & 4.15 & 2.51 & 2.20 \\
\hline Stade & $\mathrm{NI}$ & 4.64 & 4.71 & & 4.88 & 4.93 & 4.85 & 4.90 & 4.84 & 4.71 & 4.33 & 2.53 & 2.20 \\
\hline Oberfranken & BY & 4.54 & 4.71 & 5.13 & 4.78 & 4.65 & 4.44 & & 4.52 & & 4.04 & 2.66 & 2.21 \\
\hline Jagstkreis & BW & & 5.62 & 6.05 & 5.65 & 5.27 & 4.90 & & 4.64 & & 4.29 & 2.70 & 2.30 \\
\hline Mecklenburg & $\mathrm{MV}$ & 3.82 & 4.04 & 4.34 & 4.19 & 4.20 & 4.22 & & 4.06 & & 3.57 & 2.64 & 2.33 \\
\hline Unterfranken & BY & 4.57 & 4.69 & 5.11 & 4.68 & 4.38 & 4.22 & & 4.34 & & 4.07 & 2.85 & 2.35 \\
\hline Münster & NW & 3.98 & 4.09 & & 4.62 & 4.78 & 4.91 & 5.15 & 5.50 & 5.71 & 5.56 & 3.33 & 2.44 \\
\hline Trier & $\mathrm{RP}$ & 4.99 & 5.03 & & 5.26 & 5.13 & 5.15 & 5.26 & 5.39 & 5.26 & 4.80 & 3.26 & 2.45 \\
\hline Oldenburg & $\mathrm{NI}$ & 4.13 & 4.09 & 4.50 & 4.39 & 4.35 & 4.42 & 4.63 & 4.74 & 4.64 & 4.34 & 2.91 & 2.56 \\
\hline Osnabrück & $\mathrm{NI}$ & 4.28 & 4.45 & & 4.59 & 4.63 & 4.50 & 4.57 & 4.60 & 4.55 & 4.40 & 3.05 & 2.60 \\
\hline Köslin & MV & 5.10 & 5.16 & & 5.25 & 5.29 & 5.24 & 5.21 & 5.24 & 4.91 & 4.55 & 2.94 & 2.61 \\
\hline Aurich & $\mathrm{NI}$ & 4.08 & 4.19 & & 4.53 & 4.64 & 4.71 & 4.71 & 4.62 & 4.52 & 4.35 & 3.06 & 2.72 \\
\hline Oberpfalz & BY & 5.15 & 5.46 & 6.02 & 5.87 & 5.77 & 5.52 & & 5.59 & & 5.15 & 3.50 & 2.91 \\
\hline Niederbayern & BY & 5.16 & 5.46 & 5.96 & 5.93 & 5.82 & 5.64 & & 5.66 & & 5.29 & 3.52 & 2.99 \\
\hline
\end{tabular}

Source: Princeton European Fertility Project. For process of calculations, see Section 3.2 
Appendix III: $\quad C_{\mathrm{v}}$ values from respective figures above

\begin{tabular}{|c|c|c|c|c|c|c|c|}
\hline & $\begin{array}{c}\text { Figure 1: } \\
\text { Austria }\end{array}$ & $\begin{array}{l}\text { Figure 2: } \\
\text { Germany } \\
\text { pre-1940 }\end{array}$ & $\begin{array}{l}\text { Figure 3: } \\
\text { GDR }\end{array}$ & $\begin{array}{l}\text { Figure 3: } \\
\text { FRG }\end{array}$ & $\begin{array}{c}\text { Figure 3: } \\
\text { Period } \beta / \alpha \\
\text { NUTS-1 All } \\
\text { Germany }\end{array}$ & $\begin{array}{c}\text { Figure 3: } \\
C_{\mathrm{v}} \text { Period } \alpha \\
\text { NUTS-2 }\end{array}$ & $\begin{array}{l}\text { Figure 4: } \\
\text { Switzerland }\end{array}$ \\
\hline 1860 & & & & & & & 0.16 \\
\hline 1867 & & 0.10 & & & & & \\
\hline 1870 & & & & & & & 0.14 \\
\hline 1871 & & 0.10 & & & & & \\
\hline 1875 & & 0.12 & & & & & \\
\hline 1880 & 0.05 & 0.10 & & & & & 0.13 \\
\hline 1885 & & 0.11 & & & & & \\
\hline 1888 & & & & & & & 0.16 \\
\hline 1890 & 0.06 & 0.11 & & & & & \\
\hline 1895 & & 0.12 & & & & & \\
\hline 1900 & 0.07 & 0.13 & & & & & 0.18 \\
\hline 1905 & & 0.16 & & & & & \\
\hline 1910 & 0.14 & 0.17 & & & & & 0.22 \\
\hline 1920 & & & & & & & 0.28 \\
\hline 1925 & & 0.19 & & & & & \\
\hline 1930 & & & & & & & 0.30 \\
\hline 1931 & 0.09 & & & & & & \\
\hline 1933 & & 0.18 & & & & & \\
\hline 1941 & & & & & & & 0.23 \\
\hline 1950 & & & & & & & 0.23 \\
\hline 1960 & 0.06 & & & & & & 0.20 \\
\hline 1961 & 0.15 & & & & & & \\
\hline 1962 & 0.15 & & & & 0.11 & & \\
\hline 1963 & 0.14 & & & & 0.10 & & \\
\hline 1964 & 0.15 & & & & 0.11 & & \\
\hline 1965 & 0.15 & & & & 0.11 & & \\
\hline 1966 & 0.14 & & & & 0.09 & & \\
\hline 1967 & 0.13 & & & & 0.09 & & \\
\hline 1968 & 0.13 & & & & 0.09 & & \\
\hline 1969 & 0.14 & & & & 0.10 & & \\
\hline 1970 & 0.13 & & 0.06 & 0.11 & 0.12 & & \\
\hline 1971 & 0.12 & & 0.06 & 0.13 & 0.13 & & \\
\hline 1972 & 0.13 & & 0.06 & 0.13 & 0.11 & & \\
\hline 1973 & 0.12 & & 0.04 & 0.11 & 0.09 & & \\
\hline 1974 & 0.11 & & 0.04 & 0.10 & 0.08 & & \\
\hline 1975 & 0.12 & & 0.05 & 0.09 & 0.09 & & \\
\hline 1976 & 0.12 & & 0.06 & 0.09 & 0.11 & & \\
\hline 1977 & 0.12 & & 0.06 & 0.08 & 0.18 & & \\
\hline 1978 & 0.11 & & 0.04 & 0.09 & 0.20 & & \\
\hline 1979 & 0.11 & & 0.05 & 0.08 & 0.19 & & \\
\hline 1980 & 0.11 & & 0.03 & 0.08 & 0.16 & & \\
\hline 1981 & 0.09 & & 0.04 & 0.09 & 0.19 & & 0.19 \\
\hline 1982 & 0.10 & & 0.03 & 0.09 & 0.18 & & 0.20 \\
\hline 1983 & 0.09 & & 0.03 & 0.09 & 0.19 & & 0.22 \\
\hline 1984 & 0.08 & & 0.02 & 0.09 & 0.18 & & 0.21 \\
\hline 1985 & 0.08 & & 0.04 & 0.07 & 0.18 & & 0.20 \\
\hline 1986 & 0.08 & & 0.03 & 0.08 & 0.15 & & 0.20 \\
\hline 1987 & 0.08 & & 0.04 & 0.06 & 0.14 & & 0.19 \\
\hline 1988 & 0.07 & & & & 0.06 & & 0.20 \\
\hline 1989 & 0.06 & & & & 0.07 & & 0.18 \\
\hline 1990 & 0.06 & & & & 0.06 & & 0.19 \\
\hline 1991 & 0.06 & & & & 0.16 & 0.15 & 0.12 \\
\hline 1992 & 0.08 & & & & 0.22 & 0.19 & 0.12 \\
\hline 1993 & 0.07 & & & & 0.24 & 0.21 & 0.12 \\
\hline 1994 & 0.07 & & & & 0.23 & 0.20 & 0.10 \\
\hline 1995 & 0.08 & & & & 0.20 & 0.17 & 0.10 \\
\hline
\end{tabular}


614 - Stuart Basten, Johannes Huinink, Sebastian Klüsener

\begin{tabular}{|c|c|c|c|c|c|c|c|}
\hline & $\begin{array}{l}\text { Figure 1: } \\
\text { Austria }\end{array}$ & $\begin{array}{l}\text { Figure 2: } \\
\text { Germany } \\
\text { pre-1940 }\end{array}$ & $\begin{array}{l}\text { Figure } 3: \\
\text { GDR }\end{array}$ & $\begin{array}{l}\text { Figure } 3: \\
\text { FRG }\end{array}$ & $\begin{array}{c}\text { Figure 3: } \\
\text { Period } \beta / \alpha \\
\text { NUTS-1 All } \\
\text { Germany }\end{array}$ & $\begin{array}{l}\text { Figure 3: } \\
C_{V} \text { Period } \alpha \\
\text { NUTS-2 }\end{array}$ & $\begin{array}{l}\text { Figure 4: } \\
\text { Switzerland }\end{array}$ \\
\hline 1996 & 0.08 & & & & 0.17 & 0.15 & 0.09 \\
\hline 1997 & 0.07 & & & & 0.14 & 0.13 & 0.11 \\
\hline 1998 & 0.07 & & & & 0.11 & 0.11 & 0.09 \\
\hline 1999 & 0.07 & & & & 0.09 & 0.09 & 0.09 \\
\hline 2000 & 0.06 & & & & 0.07 & 0.08 & 0.09 \\
\hline 2001 & 0.07 & & & & 0.07 & 0.07 & 0.09 \\
\hline 2002 & 0.07 & & & & 0.06 & 0.07 & 0.10 \\
\hline 2003 & 0.05 & & & & 0.06 & 0.06 & 0.09 \\
\hline 2004 & 0.06 & & & & 0.05 & 0.05 & 0.08 \\
\hline 2005 & 0.06 & & & & 0.04 & 0.05 & 0.08 \\
\hline 2006 & 0.06 & & & & 0.04 & 0.05 & 0.09 \\
\hline 2007 & 0.05 & & & & 0.04 & 0.04 & 0.09 \\
\hline 2008 & 0.05 & & & & 0.04 & 0.04 & 0.08 \\
\hline 2009 & 0.06 & & & & & 0.15 & \\
\hline
\end{tabular}




\section{Comparative Population Studies - Zeitschrift für Bevölkerungswissenschaft}

wWw.comparativepopulationstudies.de

ISSN: 1869-8980 (Print) - 1869-8999 (Internet)

Published by / Herausgegeben von

Prof. Dr. Norbert F. Schneider

Federal Institute for Population Research

D-65180 Wiesbaden / Germany

Managing Editor /

Verantwortlicher Redakteur

Frank Swiaczny

Editorial Assistant /

Redaktionsassistenz

Katrin Schiefer

Language \& Copy Editor (English) /

Lektorat \& Übersetzungen (englisch)

Amelie Franke

Copy Editor (German) /

Lektorat (deutsch)

Dr. Evelyn Grünheid

\section{Layout / Satz}

Beatriz Feiler-Fuchs

E-mail: cpos@destatis.de

\author{
Scientific Advisory Board / \\ Wissenschaftlicher Beirat \\ Jürgen Dorbritz (Wiesbaden) \\ Paul Gans (Mannheim) \\ Johannes Huinink (Bremen) \\ Marc Luy (Wien) \\ Clara H. Mulder (Groningen) \\ Notburga Ott (Bochum) \\ Peter Preisendörfer (Mainz)
}

\section{Board of Reviewers / Gutachterbeirat} Martin Abraham (Erlangen) Laura Bernardi (Lausanne) Hansjörg Bucher (Bonn) Claudia Diehl (Göttingen) Andreas Diekmann (Zürich) Gabriele Doblhammer-Reiter (Rostock) Henriette Engelhardt-Wölfler (Bamberg) E.-Jürgen Flöthmann (Bielefeld) Alexia Fürnkranz-Prskawetz (Wien) Beat Fux (Zürich) Joshua Goldstein (Rostock) Karsten Hank (Köln) Sonja Haug (Regensburg) Franz-Josef Kemper (Berlin) Michaela Kreyenfeld (Rostock) Aart C. Liefbroer (Den Haag) Kurt Lüscher (Konstanz) Dimiter Philipov (Wien) Tomáš Sobotka (Wien) Heike Trappe (Rostock) 